\title{
MULTICOMPONENT SEISMIC ANALYSIS AND CALIBRATION TO IMPROVE RECOVERY FROM ALGAL MOUNDS: APPLICATION TO THE ROADRUNNER/TOWAOC AREA OF THE PARADOX BASIN, UTE MOUNTAIN UTE RESERVATION, COLORADO
}

First Technical Report - September 23, 2002 through April 31, 2003

Paul La Pointe ${ }^{1}$

Claudia Rebne ${ }^{2}$

Steve Dobbs ${ }^{3}$

Report Date: July 10, 2003

DOE Award Number: DE-FG26-02NT15451

${ }^{1}$ Golder Associates Inc.

18300 NE Union Hill Road, Suite 200

Redmond, WA 98052

${ }^{2}$ Legacy Energy Corporarion

P. O. Box 480272

Denver, CO 80248

${ }^{3}$ Red Willow Production Company

P.O. Box 737

Ignacio, Colorado 81137 
"This report was prepared as an account of work sponsored by an agency of the United States Government. Neither the United States Government nor any agency thereof, nor any of their employees, make any warranty, express or implied, or assumes any legal liability or responsibility for the accuracy, completeness, or usefulness of any information, apparatus, product, or process disclosed, or represents that its use would not infringe privately owned rights. Reference herein to any specific commercial product, process, or service by trade name, trademark, manufacturer, or otherwise does not necessarily constitute or imply its endorsement, recommendation, or favoring by the United States Government or any agency thereof. The views and opinions of authors expressed herein do not necessarily state or reflect those of the United States Government or any agency thereof" 


\begin{abstract}
This report describes the results made in fulfillment of contract DE-FG26-02NT15451, "Multicomponent Seismic Analysis and Calibration to Improve Recovery from Algal Mounds: Application to the Roadrunner/Towaoc Area of the Paradox Basin, Ute Mountain Ute Reservation, Colorado”.

Optimizing development of highly heterogeneous reservoirs where porosity and permeability vary in unpredictable ways due to facies variations can be challenging. An important example of this is in the algal mounds of the Lower and Upper Ismay reservoirs of the Paradox Basin in Utah and Colorado. It is nearly impossible to develop a forward predictive model to delineate regions of better reservoir development, and so enhanced recovery processes must be selected and designed based upon data that can quantitatively or qualitatively distinguish regions of good or bad reservoir permeability and porosity between existing well control.
\end{abstract}

Recent advances in seismic acquisition and processing offer new ways to see smaller features with more confidence, and to characterize the internal structure of reservoirs such as algal mounds. However, these methods have not been tested. This project will acquire cutting edge, three-dimensional, nine-component (3D9C) seismic data and utilize recently-developed processing algorithms, including the mapping of azimuthal velocity changes in amplitude variation with offset, to extract attributes that relate to variations in reservoir permeability and porosity. In order to apply advanced seismic methods a detailed reservoir study is needed to calibrate the seismic data to reservoir permeability, porosity and lithofacies. This will be done by developing a petrological and geological characterization of the mounds from well data; acquiring and processing the 3D9C data; and comparing the two using advanced pattern recognition tools such as neural nets. In addition, should the correlation prove successful, the resulting data will be evaluated from the perspective of selecting alternative enhanced recovery processes, and their possible implementation.

The work is being carried out on the Roadrunner/Towaoc Fields of the Ute Mountain Ute Tribe, located in the southwestern corner of Colorado. Although this project is focused on development of existing resources, the calibration established between the reservoir properties and the 3D9C seismic data can also enhance exploration success.

During the time period covered by this report, the majority of the project effort has gone into the permitting, planning and design of the 3D seismic survey, and to select a well for the VSP acquisition. The business decision in October, 2002 by WesternGeco, the projects' seismic acquisition contractor, to leave North America, has delayed the acquisition until late summer, 2003. The project has contracted Solid State, a division of Grant Geophysical, to carry out the acquisition. Moreover, the survey has been upgraded to a 3D9C from the originally planned 3D3C survey, which should provide even greater resolution of mounds and internal mound structure.

The project has also developed the initial Project Web Page. 


\section{Table of Contents}

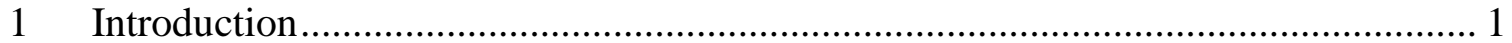

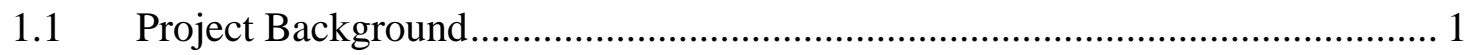

1.1.1 Undiscovered Oil Potential in the Ismay Algal Mounds .......................... 1

1.1.2 Exploration and production challenges ............................................ 3

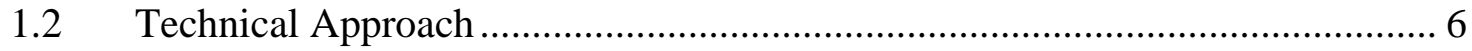

1.2.1 Main Project phases .......................................................................... 6

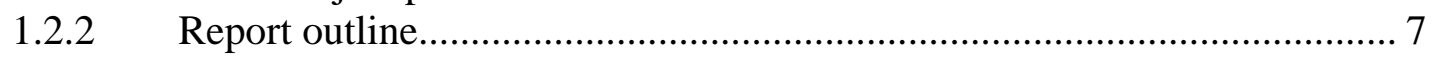

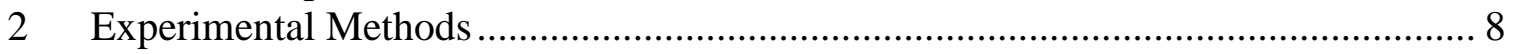

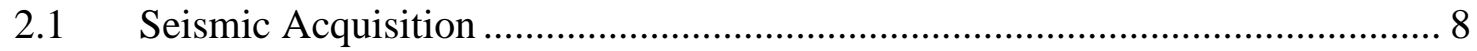

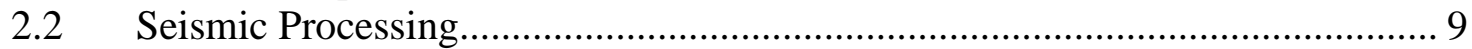

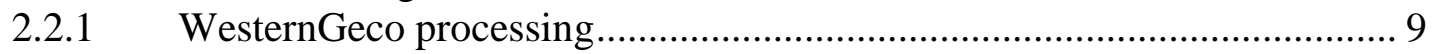

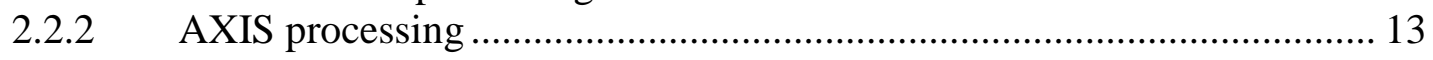

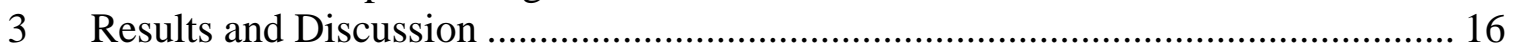

3.1 Seismic Acquisition \& Processing ........................................................... 16

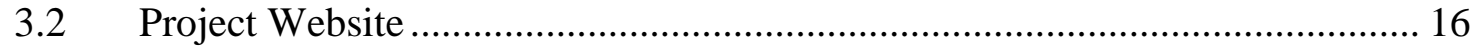

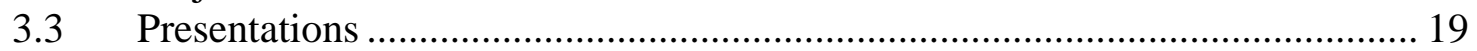

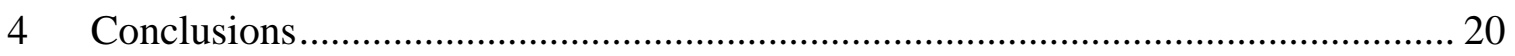

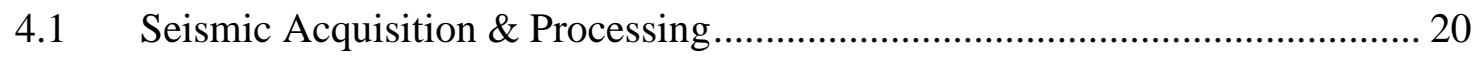

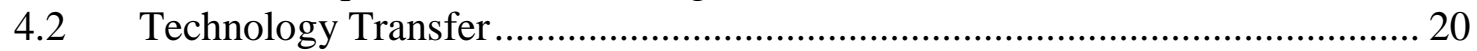

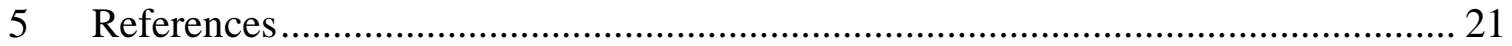

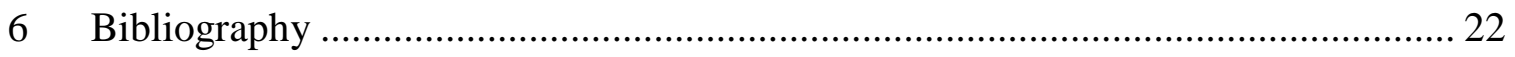

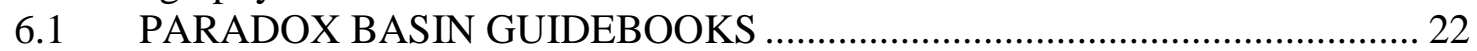

6.2 PARADOX BASIN - OIL \& GAS FIELD REFERENCES ........................... 22

6.3 PARADOX BASIN - ARTICLES ........................................................ 23

6.4 Field summaries in Clem \& Brown, 1984: ................................................... 42

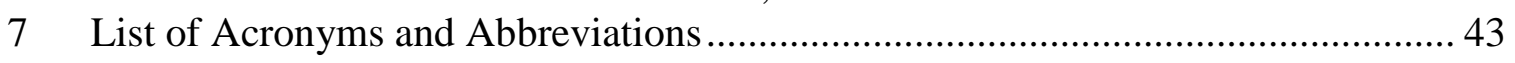




\section{List of Figures}

Figure 1-1 (above). Location of USGS's Carbonate Buildup Play (purple outline) and locations where wells have produced oil (green squares) and gas (red squares) from this play.

Figure 1-2 (right). Stratigraphic column for the prospective region............................. 1

Figure 1-3. Location map for project. The Ute Mountain Ute reservation occupies the southwestern corner of the state of Colorado (unshaded region), adjacent to the Souther Ute reservation (red cross-hatching) to the east. ........................................ 2

Figure 1-4. Hypothetical Algal Mound cross-section.................................................. 5

Figure 1-5. Cross section of two wells, one drilled on 2D seismic, the other on

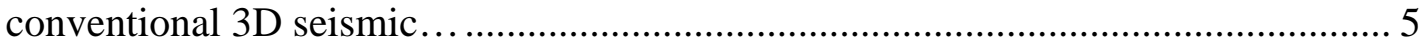

Figure 1-6. Location of the 6 square miles (outlined by red rectangle) where 3D9C seismic data will be obtained. Also shown are the outlines of existing algal mound fields

Figure 2-1. Close-up view of the 6 square miles over which 3D9C seismic data will be acquired for the project. Also shown are wells within the immediate project area... 8

Figure 3-1. Homepage and example of "Documents" subpage reached from navigation bar.

Figure 3-2. Additional subpages from the website showing the type of information that is being posted for each of the other remaining first level categories shown in the navigation bar. 18

\section{List of Tables}

Table 1-1. Relationship between reservoir properties and multicomponent attributes. Table prepared by Tom Davis, Colorado School of Mines, Phase IX Proposal, Reservoir Characterization Project (http://www.mines.edu/academic/geophysics/rcp/) .......................................... 4

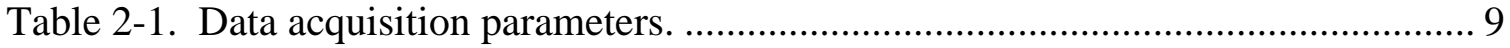




\section{INTRODUCTION}

\subsection{Project Background}

This section describes the project background. The first section summarizes the petroleum potential and geological habitat of the algal mound play in the Paradox Basin, while the second subsection summarizes the technical approach.

\subsubsection{UNDISCOVERED OIL POTENTIAL IN THE ISMAY ALGAL MOUNDS}

The U. S. Geological Survey reported in their most recent national assessment of undiscovered petroleum in the United States (Gautier and others, 1996) that the mean estimate of undiscovered oil in Porous Carbonate Buildup Play (Figure 1-1) in the Paradox Basin (Play No. 2102), of which the Ismay is the major established reservoir, is approximately $153 \mathrm{MMBO}$. They also estimate that there is a $5 \%$ probability that an undiscovered field will contain $40 \mathrm{MMBO}$, and that there would be a minimum of 10 undiscovered fields, a median of 20 undiscovered fields, and a maximum of about 50 undiscovered fields. The play is an oil and gas play. Discoveries are typically in the 1 MMBO to $10 \mathrm{MMBO}$, although the Aneth Field may contain an order of magnitude more oil in these facies

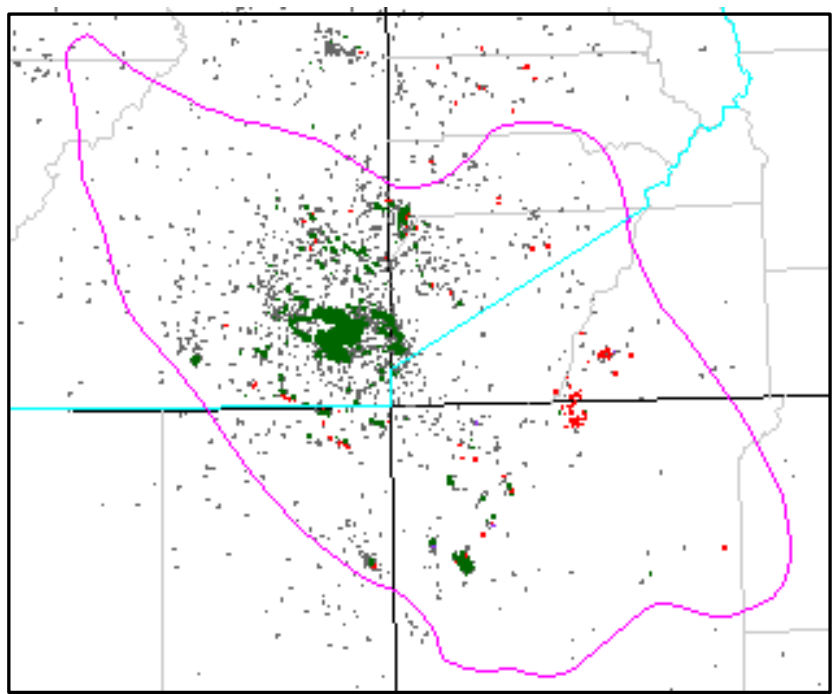

Figure 1-1 (above). Location of USGS's Carbonate Buildup Play (purple outline) and locations where wells have produced oil (green squares) and gas (red squares) from this play.

Figure 1-2 (right). Stratigraphic column for the prospective region.

\begin{tabular}{|c|c|c|}
\hline AGE & & FOAMATION OR GROUP \\
\hline \multirow{3}{*}{ CRETACEOUS } & \multicolumn{2}{|r|}{ Mesaverde Group (Ferron Ss. Member) } \\
\hline & & Mancos Shale \\
\hline & \multicolumn{2}{|r|}{$\begin{array}{l}\text { Dakota Sandstone } \\
\text { Burfo Canyon Formation } \\
\text { Morrison Formation }\end{array}$} \\
\hline JURASSIC & \multirow{2}{*}{\multicolumn{2}{|c|}{ Gien Canyon Group }} \\
\hline \multirow{3}{*}{ TRIASSIC } & & \\
\hline & & $\begin{array}{l}\text { Chinle Formation } \\
\text { Shinarump Mernber }\end{array}$ \\
\hline & & $\begin{array}{l}\text { Moenkopi Formetion } \\
\text { Timpowespo Mermber }\end{array}$ \\
\hline \multirow{3}{*}{ PEFAIAN } & \multirow{3}{*}{ 홀 } & \begin{tabular}{|c} 
Kesbab LS. / Whib Pim Ss/ De Cheley Ss \\
Organ Aock Tangue
\end{tabular} \\
\hline & & Cedar Mesa Sandabone \\
\hline & & Halgaito Tongue \\
\hline \multirow{4}{*}{ PENNSYYVANIIAN } & \multirow{3}{*}{ 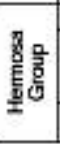 } & Honaker Trail Formation \\
\hline & & $\begin{array}{c}\text { Paradox Formalion Ismay "Zone' } \\
\text { Oesert Creek 'Zone" }\end{array}$ \\
\hline & & Pinkerton Trail Formation \\
\hline & & Molas Formation \\
\hline MISSISSIPPIAN & & Leatcille Limestone \\
\hline DEVONIAN & & $\begin{array}{l}\text { Ouray Limestone } \\
\text { Ebert Fornation } \\
\text { McCracken Mernter }\end{array}$ \\
\hline \multicolumn{3}{|l|}{$\begin{array}{l}\text { SILUPIAN } \\
\text { ORDOVICIAN }\end{array}$} \\
\hline \multirow{3}{*}{ CAMBRIAN } & & Muav Linesione \\
\hline & & Bright Angel Shale \\
\hline & & ats Sandstome L Ignacio Quarrzile \\
\hline ARCHEAN & & Igneous and metamorphic rocks \\
\hline
\end{tabular}


Figure 1-1 shows the outline of this play, along with the locations of discovered oil and gas accumulations. The Ute Mountain Ute Tribe reservation includes the southwestern Colorado portion of the play that has discovered accumulations of oil. The reservoirs are typically mounds of algal (Ivanovia) limestone associated with organic-rich black dolimtic shale and mudstone rimming evaporite sequences of the Paradox Formation of the Hermosa Group (Figure 1-2). Net pay is on the order of $3 \mathrm{~m}-15 \mathrm{~m}$ but occasionally reaches a net thickness of $30 \mathrm{~m}$. Porosities typically vary from 5\% to $20 \%$. The traps are sourced by interbedded organic-rich dolimtic shales and mudstones. Oil generation occurred from the Late Cretaceous to the Paleocene. After expulsion, oil moved updip or migrated locally. There are a variety of seals, including porosity differences, overlying evaporates and interbedded shale. Most production ranges in depth from $1500 \mathrm{~m}$ to 2000 m.

The location of the Ute Mountain Ute tribal lands are shown in Figure 1-3.

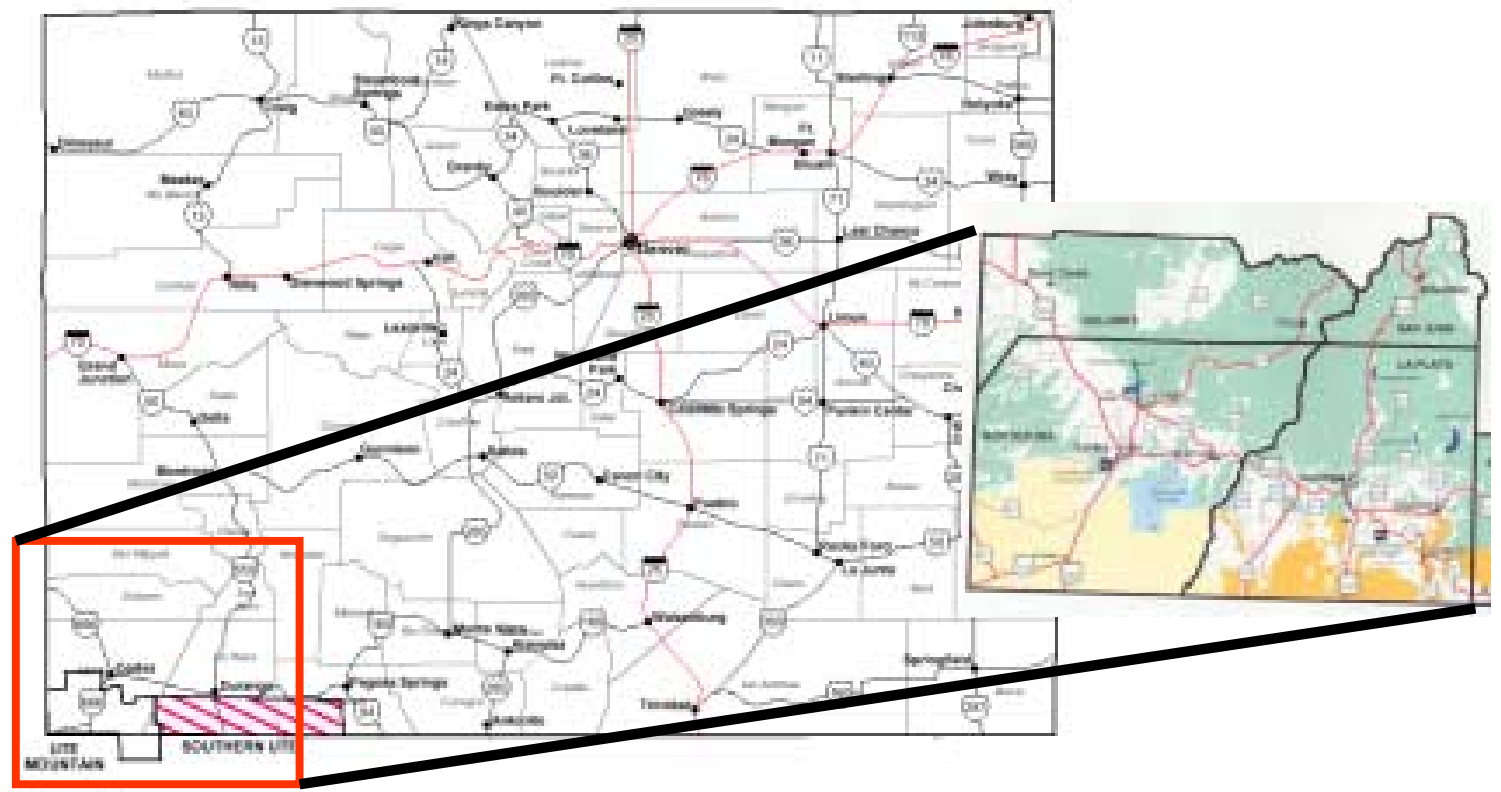

Figure 1-3. Location map for project. The Ute Mountain Ute reservation occupies the southwestern corner of the state of Colorado (unshaded region), adjacent to the Southern Ute reservation (red cross-hatching) to the east. 


\subsubsection{EXPLORATION AND PRODUCTION CHALLENGES}

Game Sixteen: December 23 - Pittsburgh at Tampa Bay.

"After analysis on Warren Sapp playing offense for the Buccs, I liken it to a 3-D seismic data with several types of seismic attributes revealing geologic factors that control the location of productive algal mound reservoirs in the Paradox Basin." (anonymous posting on sports website http://www.baseballology.com/warrzone/article.php3?ArticleID=788)

This anonymous posting on a website somewhat whimsically summarizes the technical challenges for improving exploration and production success.

The goal of this project is to detect reliably stratigraphic features that are on the order of 200 to 1000 acres (Figure 1-4). These features have little structural expression. The mounds are surrounded and overlain by massive anhydrite. The reservoir properties of these mounds are not homogeneous throughout. From the standpoint of reservoir development of an existing algal mound field, the critical factors lie in predicting the porosity, permeability, internal mound geometries and fluid content of the mounds. While well information and production data are useful in understanding some of these variations, they cannot alone be used to make more accurate descriptions of the salient reservoir parameters between well control. This requires the use of some tool that provides at least an indirect indication of these properties away from well control. For this purpose, seismic data is the most appropriate technology available.

The usefulness of seismic technology has been exemplified by industry's improved exploration success in the algal mound play in the Paradox Basin (Figure 1-5). 2D seismic was first applied in the early 1980's. Success rates for exploration wells were around 10\%. This increased to about $25 \%$ in the mid-1990's as conventional 3D seismic data was acquired for use in delineating exploration targets. Advanced multicomponent technology, such as 3D3C and 3D9C, should improve success rates in exploration even more and also provide better static reservoir models for existing fields. The key to developing a better image of the reservoir's internal geometry and flow properties is to utilize fluid saturations and azimuthal processing that can directly respond to oriented heterogeneities and changes in fluid saturations. Thus, acquisition of shear-wave data and advanced azimuthal processing or both shear- and compressional-wave data will potentially provide a much higher resolution of internal mound geometry and, from a reservoir engineering standpoint, a better model of the distribution of reservoir porosity and permeability

Table 1-1 shows the relation between multicomponent attributes and important reservoir properties. 


\begin{tabular}{|l|l|l|}
\hline Reservoir Property & Wavefield & Attribute \\
\hline Porosity & P, S, PS & $\begin{array}{l}\text { Amplitude, shear wave } \\
\text { splitting }\end{array}$ \\
\hline Permeability & P, S & $\begin{array}{l}\text { Energy flow }{ }^{1} \text { shear wave } \\
\text { splitting direction }\end{array}$ \\
\hline Saturation & S & Shear wave splitting \\
\hline Viscosity & S & Frequency and attenuation ${ }^{2}$ \\
\hline Density & P, S, PS & $\begin{array}{l}\text { Amplitude variation with } \\
\text { offset (AVO) }\end{array}$ \\
\hline Structure & Pravel-time \\
\hline
\end{tabular}

product of P- and S-wave amplitude at zero offset

2 e.g. Duranti (2001) and Michaud (2001)

${ }^{3}$ Amaral (2001)

Table 1-1. Relationship between reservoir properties and multicomponent attributes. Table prepared by Tom Davis, Colorado School of Mines, Phase IX Proposal, Reservoir Characterization Project (http://www.mines.edu/academic/geophysics/rcp/)

As with any indirect means of detection, such as seismic data, the multicomponent attribute data needs to be calibrated; a connection needs to be made between the indirect data and the parameters of interest, in this case, the facies and their reservoir properties. The relations between 3D9C data and reservoir properties like porosity, permeability, internal mound geometry and fluid content of the mounds have not yet been exhaustively established through years of experience. There need to be calibration studies carried out to support the establishment of these links. For this reason, the proposed project also contains work by a petrologist highly familiar with Paradox Basin algal mound fields, and by geologists who are experienced in developing sophisticated predictive reservoir models to help establish these linkages. The proposed project not only includes a geological and petrological description, but goes an important step further and examines the relation of these parameters to quantitative production measures of individual wells and the field as a whole.

The project will develop and test a method to improve reservoir development by utilizing a new and appropriate seismic technique (3D9C) and carrying out the necessary work to relate this indirect data arising from the 3D9C survey to the reservoir parameters and ultimately the producing characteristics of an algal mound field. As a result, the proposed multidisciplinary technical approach is both reasonable and adequate to meet the project goal of improving recovery from algal mound fields through better reservoir characterization presented in a way that helps production engineers plan wells or design recovery processes.

Likewise, exploration success can be improved using the calibrated Multicomponent data. The resulting processed and calibrated seismic data should provide much more accurate and higher resolution of the lithologic facies variations that delineate mounds 


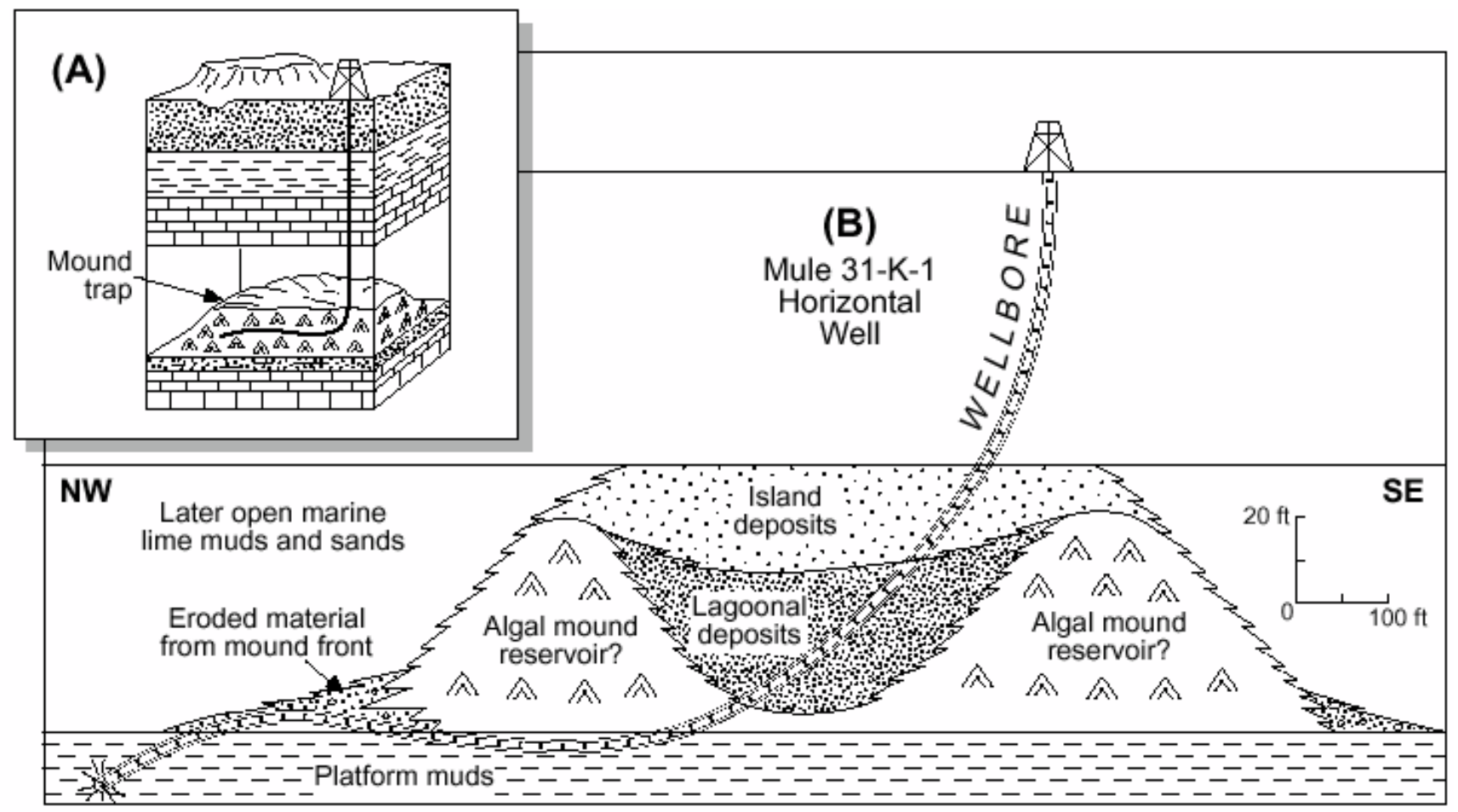

Figure 1-4. Hypothetical Algal Mound cross-section

(A) Schematic block diagram of a horizontal well penetrating a small algal-mound oil trap, and (B) a vertical cross section of the rocks below ground surface in the Mule mound penetrated by the Mule No. 31-K-1 horizontal well.

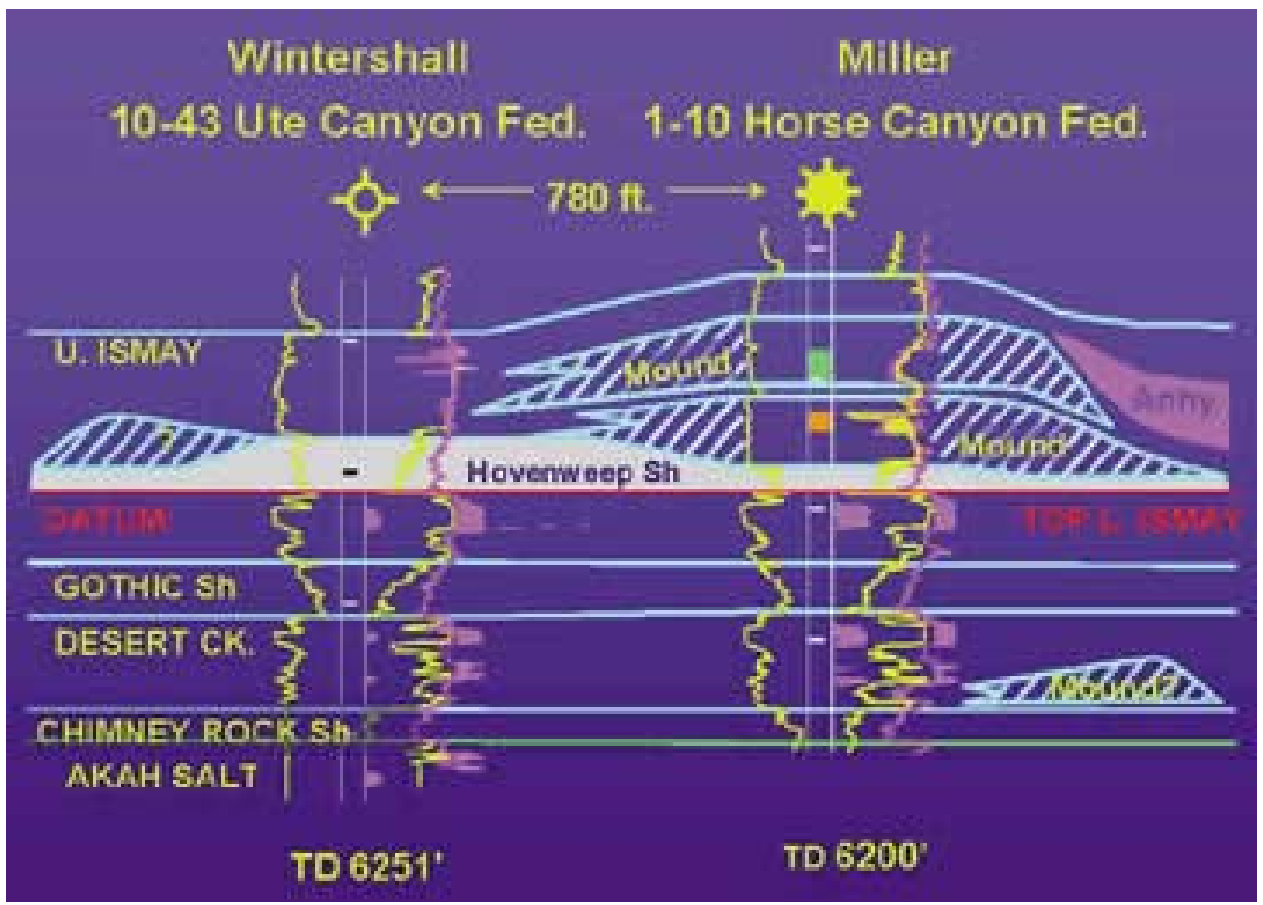

Figure 1-5. Cross section of two wells, one drilled on 2D seismic, the other on conventional 3D seismic. The Horse Canyon Federal \# I - I 0 well was drilled just south of the Blanding Prospect Area by Miller Energy in 1998. This well location was based on 3D seismic data, and is only 700 feet away from a dry hole drilled in the 1980s based on 2D seismic data. The well IP'd for 960 BOPD and 3 MMCFGPD. This is a good case history illustrating that the older 2D seismic data did reliably detect a mound, but the 3D seismic data was required to image the productive portion of the mound and resulted in a prolific new discovery. 


\subsection{Technical Approach}

\subsubsection{MAIN PROJECT PHASES}

The main steps in the project are outlined below:

1. Acquire 3D Multi-Component data over existing algal mound production as well as off-mound area (Towaoc \& Roadrunner Fields)

2. Acquire a Multi-Component VSP (vertical seismic profile) in a well to help calibrate 3D processing and acquisition

3. Process 3D data for P-wave, S-wave, P-S wave, AVO and anisotropic velocity attributes

4. Calibrate processed seismic data against core a facies interpretations

5. Calibrate processed seismic data against reservoir engineering data

The seismic data will be acquired over portions of two existing fields, Towaoc and Roadrunner (Figure 1-6), as well as non-productive acreage in between, as calibration needs both positive and negative information.

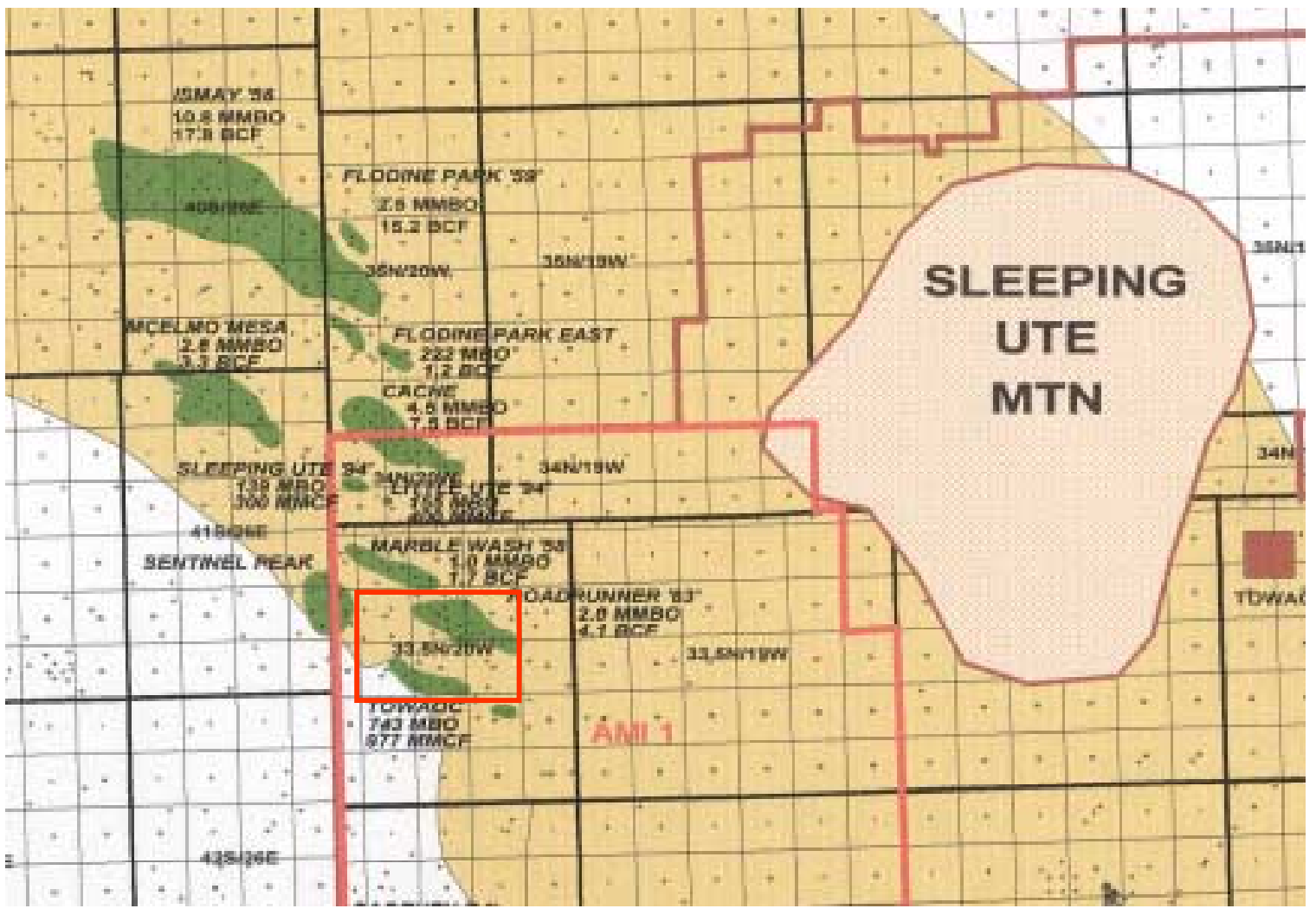

Figure 1-6. Location of the 6 square miles (outlined by red rectangle) where 3D9C seismic data will be obtained. Also shown are the outlines of existing algal mound fields. 
In addition to the seismic data to be acquired, additional existing data, listed below, may be used as needed.

\section{Core and Well Data}

- 10 cores in either the Upper or Lower Ismay in the immediate area. Including relevant core from the surrounding area a total of 500 feet of core.

- 34 wells with well histories and conventional logs. 19 of the 34 wells are producing wells and have production data

- $\quad$ Detailed tops database and subsurface mapping (Red Willow)

\section{Existing Seismic Data}

- 600 miles of conventional 2-D data already acquired. 100 miles of which have been reprocessed by Red Willow.

\subsubsection{REPORT OUTLINE}

The remainder of this report describes the progress made to date. In the fall of 2002, WesternGeco, who had been the project's seismic acquisition contractor, decided to no longer provide this service in North America. The contract was opened to re-bid among those companies able to acquire this type of data, and SolidState, a division of Grant Geophysical has been selected based on cost and crew availability. Also during the rebid process, the project was able to upgrade the seismic survey from 3D3C to 3D9C. The difference between these two surveys is that the 3D9C survey uses orthogonal shear wave sources, as well as records the seismic waves using orthogonal horizontal geophones. Shear wave sources are oriented inline and crossline to the receiver lines, as are the horizontal geophones. Additional information concerning 3D9C surveys, acquisition and processing can be found in Simmons and Backus (2001).

Section 2 describes the experimental methods used to date, which consists of the design of the seismic survey and the seismic processing approach.

Section 3 describes and discusses results to date. As the seismic data have not yet been acquired, the primary project accomplishments have been in the permitting process leading to the acquisition and establishment of the project website.

Section 4 describes conclusions. 


\section{EXPERIMENTAL METHODS}

\subsection{Seismic Acquisition}

Figure 2-1 shows a more detailed view of the area over which the 3D9C seismic data will be acquired for the project pending approval of all permits. In this figure, the six square miles (approx. $15.54 \mathrm{~km}^{2}$ ) are shaded.

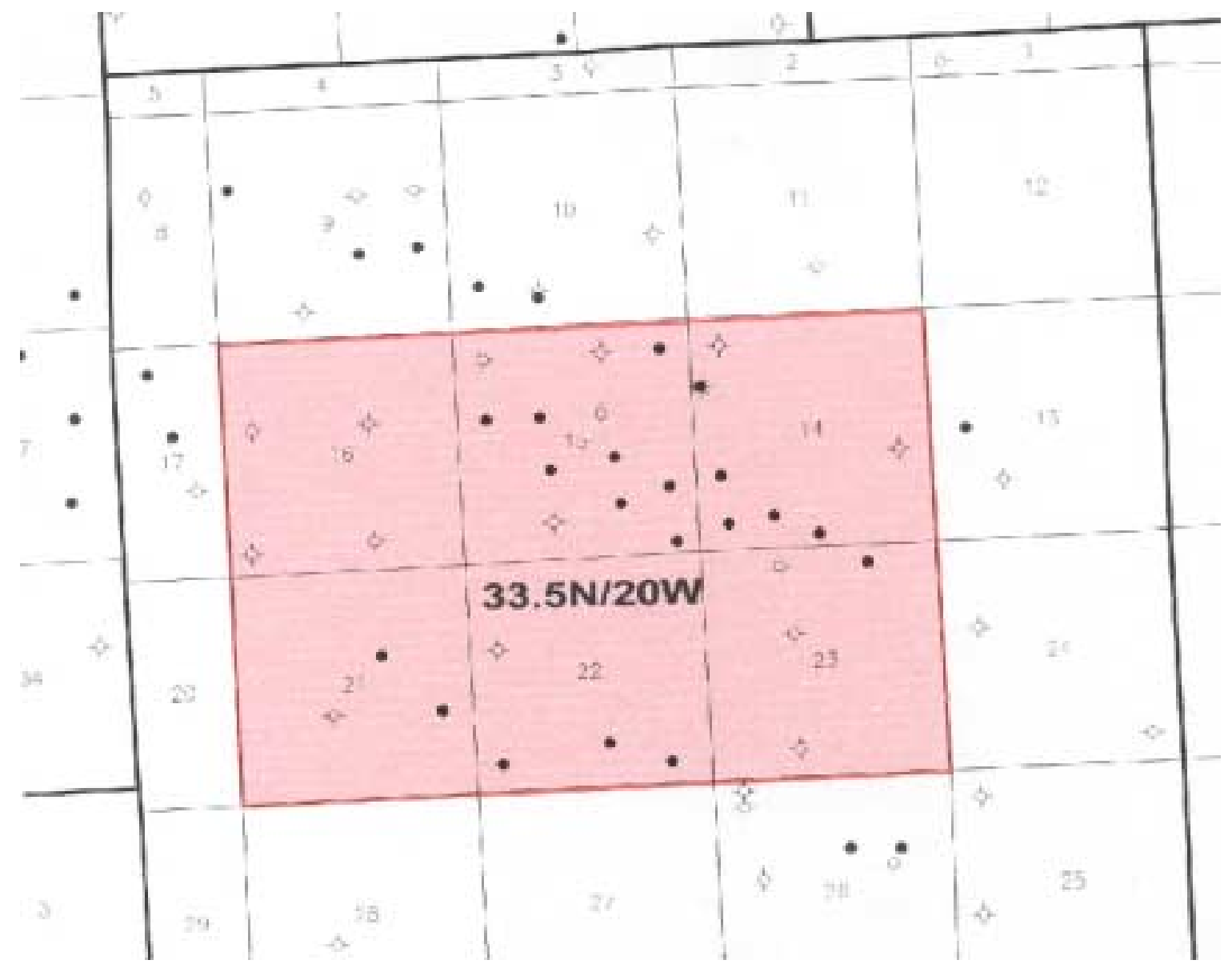

Figure 2-1. Close-up view of the 6 square miles over which 3D9C seismic data will be acquired for the project. Also shown are wells within the immediate project area.

Table 2-1 shows the data acquisition parameters for the 3D9C shoot. 
Program Size:

Line Parameters

Receiver point interval

Source point interval

Total receiver points

Total source points

\section{Source Type for programs}

P Waves
Shear 1
Shear 2
I.V.I Triax Vibrator
Record Length

Recording Parameters

Geophone array

Live patch

Roll on / roll off

Filters

Sample Rate
6.0 square miles

$220 \mathrm{ft}$

$220 \mathrm{ft}$

1225

576

4 sweeps $\times 10$ seconds

4 sweeps $\times 10$ seconds

4 sweeps $\times 10$ seconds

6 seconds

6 over $45 \mathrm{ft}$

18 lines $X 60$ channels

Yes

$1 / 2$ Niquist

$2 \mathrm{~ms}$

Table 2-1. Data acquisition parameters.

\subsection{Seismic Processing}

The seismic data processing will be carried out by WesternGeco and by AXIS. A description of the processing carried out by Western Geco is described in Section 2.2.1; the processing carried out by AXIS is described in Section 2.2.2.

\subsubsection{WESTERNGECO PROCESSING}

\subsubsection{Compressional Wave Processing}

The following 14 steps describe the compressional wave processing:

1. Pre-processing, consisting of

- data transfer

- display of shot records and deletion of bad traces

- define geometry, compute field static corrections

- spherical divergence compensation and trace balance

- grid data in appropriate surface bins

2. Noise attenuation (any combination)

- f-x Coherent Noise Suppression 
- Adaptive Noise Cancellation

- f-k Filter

3. Signal processing (any combination)

- Surface-consistent or trace-by-trace deconvulation

- Model-based wavelet processing

- Time variant spectral whitening

4. Preliminary stack

- Stack with signal processing and regional velocity

5. 3-D refraction statics

- First-break picking of all records

- Offset and weathering velocity testing

- Stack with signal processing and refraction statics

6. 3-D velocity analysis

7. Surface-consistent $3 \mathrm{D}$ residual reflection statics

8. NMO and trim statistics, if appropriate

9. EQ DMO and stack

10. Spectral whitening

11. Random noise attenuation (f-xy deconvolution)

12. Time-variant filter and scaling

13. Time migration

14. Spectral whitening

\subsubsection{Shear Wave Processing}

1. Pre-processing

- Data transfer

- Display shot records and delete bad traces

- Define geometry - compute field static corrections

- Extract S-wave components

- Spherical divergence compensation and/or trace balance

- Grid data

2. Noise attenuation (any combination)

- f-x Coherent Noise Suppression

- Adaptive Noise Cancellation

- f-k filter

3. Signal processing (any combination)

- Determine S1/S2 orientation of the overburden and rotate to S1/S2 coordinate system

- Surface-consistent amplitude compensation

- Surface-consistent deconvolution

- Model-based wavelet procession

- Model-based Q compensation

- Time-variant spectral whitening

4. Preliminary stack

- Stack with signal processing and regional velocity 
5. 3-D refraction statics

- First-break picking of all records

- Offset and weathering velocity testing

- 3D refraction tomography

- Use PS detector statics or hand statics as applicable

6. 3-D velocity analysis

- Azimuth limited as needed

7. Surface-consistent 3D residual reflection statics

8. 3-D velocity analysis

- Azimuth limited as needed

9. Surface-consistent 3D residual reflection statics

10. NMO and mute

11. EQ DMO and stack

12. Spectral whitening, as needed

13. Random noise attenuation (f-xy deconvolution)

14. Time-variant filter and scaling

15. Time migration

- Full wavefield Extended Stolt

- Modified residual method

\subsubsection{3 $P$ to $S$ Converted Wave}

1. Pre-processing

- Data transfer

- Display shot records and delete bad traces

- Define geometry - compute field static corrections

- Spherical divergence compensation and/or trace balance

- Grid data

- Verify orientation of H1 and H2

2. Noise attenuation (any combination)

- $\mathrm{f}$-x Coherent Noise Suppression

- f-k filter

3. Receiver rotation to radial and transverse

4. Determine $\mathrm{S} 1$ and $\mathrm{S} 2$ from supergathers and restrict azimuths (if appropriate)

- Receiver rotation to S1 and S2 (if appropriate)

- Proceed with limited-azimuth volumes for statics, CCP binning and velocities

5. Signal Processing (any combination)

- Surface-consistent deconvolution

- Model-based wavelet procession

- Time-variant spectral whitening

6. Preliminary stack

- Estimate preliminary $\gamma_{0}$

- Stack with signal processing and regional velocity

7. P-wave source statics application 
8. 3-D velocity analysis

9. Receiver statics computed from common-receiver gathers/stacks

10. Surface-consistent 3D residual reflection statics

11. P-S common conversion point (CCP) binning

- Depth-dependent correction

- Measure $\gamma_{0}$ from P-wave stack and preliminary PS-wave stack

- Compute CCP locations using $\gamma_{\mathrm{o}}$ and $\gamma_{\mathrm{eff}}$

12. 3-D velocity analysis

13. Surface-consistent 3D residual reflection statics

14. Multi-window P-S common conversion point (CCP) binning

- Depth-dependent correction

- Measure $\gamma_{0}$ from P-wave stack and preliminary PS-wave stack

- Compute CCP locations using $\gamma_{o}$ and $\gamma_{\text {eff }}$

15. 3-D velocity analysis

16. Iterate steps $13-15$ as needed

17. Higher order moveout (if necessary)

18. 3-D velocity analysis

19. Final CCP bin

20. P-S DMO (if necessary)

21. Stack

22. Random noise attenuation (f-xy deconvolution)

23. Time-variant filter and scaling

24. P-S migration

25. Process transverse (or S2) component using parameters from radial (or S1)

\subsubsection{Azimuthal Anisotropy Analysis (S-wave only)}

1. 2Cx2C Alford rotation of volumes to S1/S2 and two off-diagonal components

2. Rotation and layer stripping analysis at horizons of interest

\subsubsection{Azimuthal Anisotropy Analysis (PS-wave only)}

1. Receiver rotation to radial and transverse

2. Azimuth limit radial and transverse volumes to 8 azimuth sectors $(0-360 \times 45$ degrees); 16 total volumes

3. NMO and stack

4. Random noise attenuation (f-xy deconvolution)

5. Time-variant filtering and scaling

6. P-S time migration

7. $2 \mathrm{C} \times 2 \mathrm{C}$ Alford rotation of volumes to $\mathrm{S} 1 / \mathrm{S} 2$ and two off-diagonal components

8. Combine all azimuth volumes into one $2 \mathrm{C}$ by $2 \mathrm{C}$ set

9. Rotation and layer stripping analysis at horizons of interest 


\subsubsection{Summary of Data Deliverables from Processing}

1. Final PP DMO stack and migration volumes - P-wave

2. Final ShSh DMO stack and migration volumes - S-wave

3. Final SvSv DMO stack and migration volumes $-\mathrm{S}$-wave

4. Final ShSv DMO stack and migration volumes - Off-diagonal S-wave

5. Final SvSh DMO stack and migration volumes - Off-diagonal S-wave

6. Final PS CCP stack and migration volumes - mode-converted wave (radial component or S1)

7. Final PS CCP stack and migration volumes - mode-converted wave (transverse component or S2)

8. Fold map - CMP binning

9. Fold map - CCP binning at target horizon)

10. Vp stacking velocity field

11. Vsh stacking velocity field

12. Vsv stacking velocity field

13. Vps stacking velocity field

14. Vp/Vs voloume from PS CCP binning run

15. Detailed processing report

\subsubsection{AXIS PROCESSING}

\subsubsection{Azimuthal Processing Approach}

AXIS will additionally process the 3D9C seismic data to further extract useful information. Without azimuthal processing the following problems can occur if the rock possesses azimuthally-varying velocity and this is not taken into account during processing:

- Affects processing quality and resolution

- Requires high-resolution velocity analysis

- Causes a regional velocity overprint

- Causes mis-stacking near faults

- Affects 2-D and narrow azimuth 3-D data

- Causes acquisition footprint when uncorrected

- Affects time-lapse 3-D comparisons

- Makes AVO analysis impossible

- Bleeds into azimuthal AVO analysis

On the other hand, when the azimuthal velocity is properly taken into account during processing, the resulting data has much greater utility for a variety of exploration and production uses. In particular, the data can be used to provide much more reliable data on: 
- Fracturing below isotropic seals

- Analysis for water coning

- Analysis for water and CO2 floods

- Drilling hazard analysis and horizontal well planning

- Analysis for tight gas sweet spots

- Correct velocities for depth conversion and pressure/gas saturation prediction

- Subtle structure depth conversion

- Less 3-D footprint

- Better data quality because of higher useful fold

- Better frequency content because of proper stacking

- Better surface consistent statics solutions

- Zero offset well ties

\subsubsection{Data Processing Steps \& Resulting Data Sets}

The processing can be separated into three portions: azimuthal velocity analysis, isotropic AVO, and azimuthal AVO.

During the azimuthal velocity analysis every $3 \times 3$ CDP will be analyzed. This will result in seven data volumes:

- RMS Vfast (RMS velocity of fast propagation direction)

- RMS Vfast minus Vslow (RMS velocity magnitude difference)

- RMS Error (Estimated error in RMS Vfast)

- RMS Azimuthal Direction (Direction of Vfast)

- Interval Vfast (Interval velocity of fast propagation direction)

- Interval Vfast minus Vslow (Interval velocity magnitude difference)

- Interval Vfast Azimuthal Direction

The isotropic AVO analysis will employ a three-term fit for all angles. This will produce:

- Migrated intercept

- Migrated gradient

- Migrated Third Term

- Damped Migrated Third Term in high confidence areas

The final stage of processing, azimuthal AVO, will produce an additional three data sets:

- $\quad$ Migrated G1-G2 (High minus low gradient)

- Migrated G1 Azimuthal Direction

- Migrated G1-G2 Error 
Some of these data volumes produced during processing will be used to develop the calibration for detecting algal mounds and delineating their internal geological and fluid geometries. Other data volumes serve the role as quality checks, so that the areas where a particular data volume may be less reliable can be assessed and identified. 


\section{RESULTS AND DISCUSSION}

\subsection{Seismic Acquisition \& Processing}

At this point, permitting for the seismic acquisition is nearing completion, and as such, no data have yet been acquired or processed.

Permitting of the 3D9C seismic survey was initiated in April, 2003. Initial surveying of source and receiver points has been completed. Field archeological and biological work was conducted in May and June of 2003. The final Archaeological Report and Environmental Assessment are currently being prepared. All permit documents and maps are scheduled to be submitted to the Bureau of Indian Affairs (BIA) in the week of July $14^{\text {th }}$.

The BIA will review the Environmental Assessment and then provide for a 30-day public comment period. The Colorado State Historical Preservation Office (SHIPO) will have 30 days to review the Archeological Report and make comments or suggestions. This suggests that permitting could be completed as early as late August.

Red Willow Production met with Rim Operating Company in April to discuss wellbore access for the VSP. Rim has agreed to provide access and Red Willow has prioritized potential wells for the VSP. Currently, a Red Willow engineer is evaluating candidate wells to insure that the wellbores are adequate for the VSP data collection

\subsection{Project Website}

A project website has been initiated for the project. The homepage for this project is at: http://thebe.golder.com/utemtn/Home/. Figure 3-1 shows the homepage (with a view of Ute Mountain), along with some of the basic structure of the web site. On the homepage, there is a navigation bar that takes the visitor to Background, Gallery, Documents Feedback and Links subpages. Also shown in the figure is the Documents subpage and one of its subpages, "Other". There is also a scrolling window on the right that lists the latest project news.

Documents contains the written record of the project, including Progress Reports, informal and professional society presentations, and others, such as the bibliography (see Section 6 of this report) prepared by team member Claudia Rebne of Legacy Energy.

Figure 3-2 shows some of the content being assembled for the subpages. For example, in the Background section, there is a description of the project Task by Task; project data available for download as it becomes available); the project schedule and the project team. It is here that the visitor can learn about the technical workflow of the project, why the project is being done, who the principal participants are, and download selected data. 


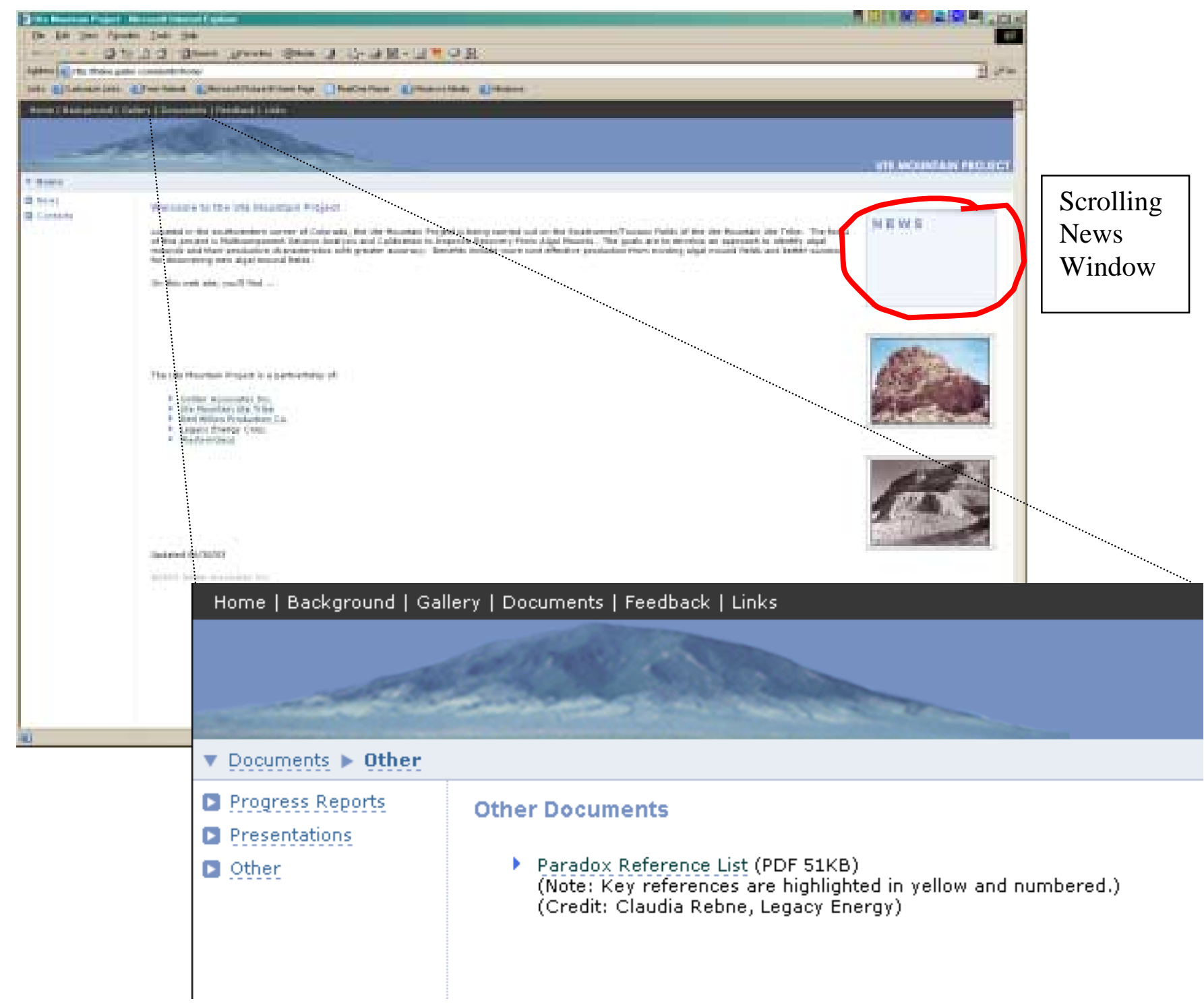

Figure 3-1. Homepage and example of "Documents" subpage reached from navigation bar.

The Gallery will contain photos, drawings and other graphic material related to the project. Currently there are three subdivisions in this page for showing the project location, with particular reference to the seismic grid, and will contain photos of the seismic shoot when it occurs and other photos having to do with the Paradox Basin, the geological data obtained that is of a graphic nature, and other project-related photos.

Documents contains the written record of the project, including Progress Reports, informal and professional society presentations, and other, such as the bibliography prepared by team member Claudia Rebne of Legacy Energy, and listed also in this report.

The Feedback subpage allows visitors to email questions, comments or requests to the project team members, to assist in communicating the technical achievements and findings of the project to others. 
Home | Background | Gallery | Documents | Feedback | Links

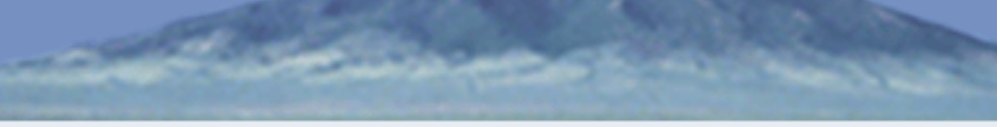

$\nabla$ Links $>$ Project Participants

- Tribal Information

Project Participants

D DOE Sponsored

Projects

- Project Participants

D Other

- Axis Geophysics

- Red willow Production Company

- Solid State Geophysical

- westernGeco
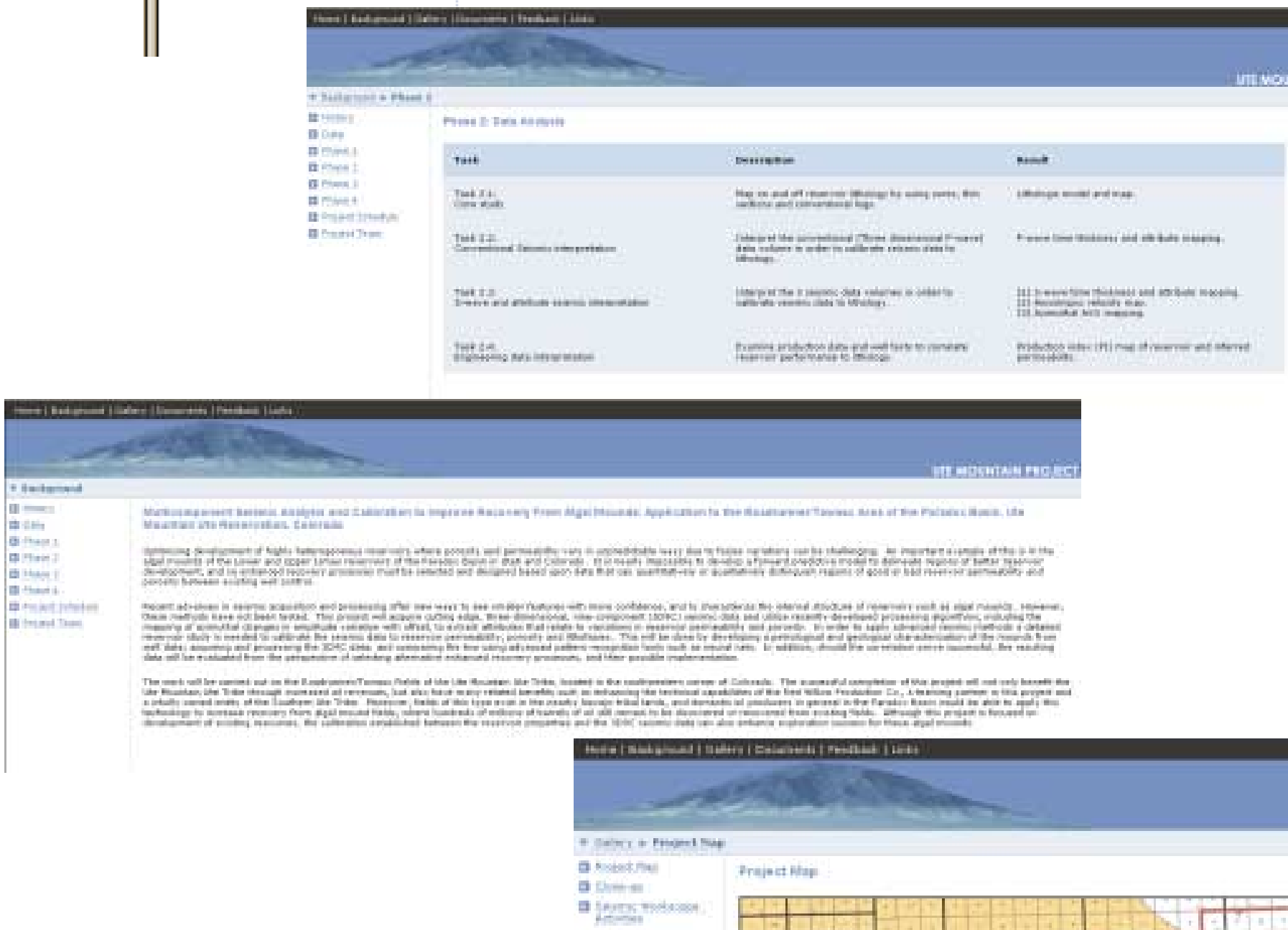

Figure 3-2. Additional subpages from the website showing the type of information that is being posted for each of the other remaining first level categories shown in the navigation bar.

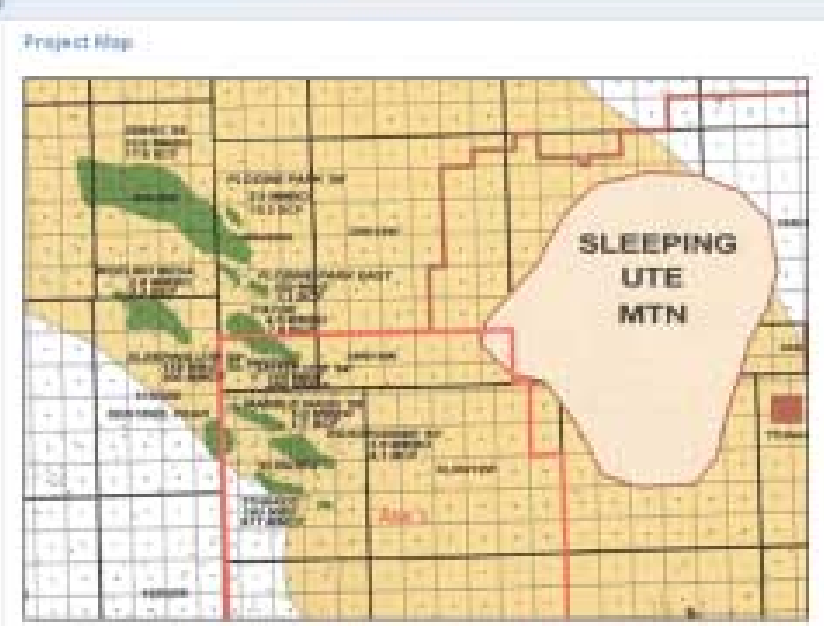


The Links section provides links to project member web pages, to the DOE's Fossil Energy sites of interest, to the Ute Mountain and Southern Ute Tribes' homepages, and to other websites that might be of general interest. New content is being added on a regular basis, and with the approaching field acquisition program, the amount of content should greatly increase over the next few months.

\subsection{Presentations}

No formal professional society presentations have been made at this point, and this current report is the first technical Progress Report.

In March, a brief informal presentation on the project was made in Durango, CO to a representative of the Ute Mountain Ute Tribe and the Tribe's chief production engineer at their Tribal Facility. Team members from Legacy Energy and Red Willow were also in attendance, and planning for the field acquisition was carried out. The presentation has been posted to the project website under the Documents > Presentations > Other subpage. The file is overview.ppt, and contains a brief overview of the project activities, structure, participants and goals.

Also, in April, Claudia Rebne of Legacy Energy made an informational presentation of the project to the Colorado School of Mines Reservoir Characterization Group. Approximately 100 industry participants, students and faculty were in attendance. 


\section{CONCLUSIONS}

\subsection{Seismic Acquisition \& Processing}

Despite the loss of the original seismic acquisition contractor in the Fall of 2002, the project was successful in obtaining a new contractor at an equivalent cost. Permitting is nearing completion, and acquisition is planned for late August or early September, with processing taking place immediately following.

\subsection{Technology Transfer}

The project website has been published, and currently contains background information on the project, with the structure to accommodate substantial additional project content as it becomes available from the acquisition and processing. 


\section{REFERENCES}

Amaral, L., 2001. Shear wave azimuthal AVO analysis, Vacuum Field, New Mexico. MS Thesis T-5467, Colorado School of Mines

Duranti, L. 2001. Seismic analysis of reservoir dynamics. Ph. D. Thesis, (inprogress), Colorado School of Mines

Michaid, G. 2001. Time-lapse multicomponent borehole seismic monitoring of a pilot $\mathrm{CO}_{2}$ flood. Ph. D. Thesis T-5506, Colorado School of Mines.

Simmons, J and M. Backus, 2001. Shear waves from 3-D-9-C seismic data. The Leading Edge, June 2001, 604-612. 


\section{BIBLIOGRAPHY ${ }^{1}$}

\subsection{PARADOX BASIN GUIDEBOOKS}

Bass, R.O., and Sharps, S.L., eds., 1963, Shelf carbonates of the Paradox Basin: Four Corners Geological Society $4^{\text {th }}$ Field Conference, $273 \mathrm{p}$.

Campbell, J.A., ed., 1987, Geology of Cataract Canyon and Vicinity: Four Corners Geological Society $10^{\text {th }}$ Field Conference.

Cooper, J.C., ed., 1955, Geology of parts of Paradox, Black Mesa and San Juan Basins: Four Corners Geological Society.

Fassett, J.E., and Wengard, S.A., 1975, Canyonlands Country: Four Corners Geological Society Guidebook $8^{\text {th }}$ Field Conference.

Four Corners Geological Society, 1952, Geological Symposium of the Four Corners Region, $145 \mathrm{p}$.

Grand Junction Geological Society, 1983, Northern Paradox Basin-Uncompaghre Uplift.

Huffman, C.A., Lund, W.R., and Godwin L.H., eds., 1996, Geology and Resources of the Paradox Basin: Utah Geological Association \& Four Corners Geological Society Guidebook 25, 460 p.

Sanborn, A.F., ed., 1958, Guidebook to the geology of the Paradox Basin: Intermountain Association of Petroleum Geologists $9^{\text {th }}$ Annual Field Conference.

Smith, K.G., ed., 1960, Geology of the Paradox fold and fault belt: Four Corners Geological Society $3^{\text {rd }}$ Field Conference, $173 \mathrm{p}$.

Wiegand, D.L., ed., 1981, Geology of the Paradox Basin: Rocky Mountain Assoc. of Geol., 285 p.

\subsection{PARADOX BASIN - OIL \& GAS FIELD REFERENCES}

Broadhead, R.F., and J.M. Robertson, Project Managers, 1993, Atlas of Major Rocky Mountain Gas Reservoirs: New Mexico Bureau of Mines and Mineral Resources, $206 \mathrm{p}$.

${ }^{1}$ Bibliography prepared by C. Rebne, Legacy Energy 
Clem, K.M. and Brown, K.W., 1984, Petroleum Resources of the Paradox Basin: Utah Geological and Mineral Survey Bull. 119, 162 p.

Fassett, J.E, ed., 1978, Oil and Gas Fields of the Four Corners Area: Four Corners Geological Society, v. 1 and 2, 726 p.

Fassett, J.E, ed., 1983, Oil and Gas Fields of the Four Corners Area: Four Corners Geological Society, v. 3, 729-1432 p.

Hill, B.G., and Bereskin, S.R., eds., 1993, Oil and Gas Fields of Utah: Utah Geological Association Publication 22.

Hill, B.G., and Bereskin, S.R., eds., 1996, Oil and Gas Fields of Utah (Addendum 1996): Utah Geological Association Publication 22.

Kuhn, P.J., ed., 1958, Oil and Gas in the Four Corners: National Petroleum Bibliography, Amarillo, TX.

\subsection{PARADOX BASIN - ARTICLES}

Amateis, L.J., and Hall, S., 1997, Drilling multilaterals in a complex carbonate reservoir, Aneth field, Utah, in E.B. Coalson, J.C. Osmond, and E.T. Williams, eds., Innovative Applications of Petroleum Technology in the Rocky Mountain Area: RMAG Symposium, p. 125-136.

Baars, D.L., 1966, Pre-Pennsylvanian paleotectonics of southwestern Colorado and east central Utah: Ph.D. Thesis, University of Colorado.

Baars, D.L, 1966, Pre-Pennsylvanian paleotectonics - key to basin evolution and petroleum occurrences in Paradox Basin, Utah and Colorado: AAPG Bulletin, v. 50, no. 10, p. 2082-2111.

Baars, D.L., 1980, Developments in Four Corners-Intermountain Area in 1979: AAPG Bulletin, v. 62, p. 1340-1344.

Baars, D.L, Parker, J.W., and Chronic, J., 1967, Revised stratigraphic nomenclature of Pennsylvanian system, Paradox Basin: AAPG Bulletin, v. 51, p. 393-403.

1. Baars, D.L. and Stevenson, G.M., 1981, Tectonic evolution of the Paradox Basin, in D.L. Wiegand, ed., Geology of the Paradox Basin: RMAG, p. 23-31.

Baars, D.L. and Stevenson, G.M., 1982, Subtle stratigraphic traps in Paleozoic rocks of Paradox Basin, in M.T. Halbouty, ed., The deliberate search for the subtle trap: AAPG Memoir 32, p. 131-158. 
Baker, A.A., Dane, C.H., and Reeside, J.B., 1933, Paradox Formation of eastern Utah and western Colorado: AAPG Bulletin, v. 17, p. 963-980.

Barker, C.E., Nuccio, V.F., Crysdale, B.L., Szmajter, R.J., Daws, T.A., and Threlkeld, C.N., 1996, Rock-Eval pyrolysis data for petroleum-potential evaluation based on well cuttings and core sample collected in 1990-1991 from the Paradox Basin, Colorado and Utah: USGS Open File Report, 27 p. 1 table.

Barker, C.E., Szmajter, R.J., Daws, T.A., and Threlkeld, C.N., 1996?, Initial results from Rock- Eval pyrolysis of potential source rocks, Paradox Basin, Utah and Colorado: USGS Circular. $5 \mathrm{p}$.

Bass, N.W., 1944, Paleozoic stratigraphy as revealed by deep wells in parts of southwest Colorado, northwest New Mexico, northeast Arizona and southeast Utah: USGS Preliminary Chart 7, Oil and Gas Investigations Series, p. 1-20.

Bergeon, T.C., 1986, Seismic character study Ismay cycle, Paradox Formation, Paradox Basin, southwest Colorado: M.S. Thesis, Colorado School of Mines.

Best, D.A., Wright, F.M., Sagar, R., and Weber, J.J., 1995, Contribution of outcrop data to improve understanding of field performance - rock exposures at Eight Foot Rapids tied to the Aneth field, in Stout, E.L., and Harris, P.M., eds., Hydrocarbon reservoir characterization - geologic framework and flow unit modeling: SEPM Short Course No. 34, p. 31-50.

Bradley, G.A., 1975, Lisbon Field, Utah: Four Corners Geological Society $8^{\text {th }}$ Field Conference Guidebook, p. 277-278.

Brinton, L., 1986, Deposition and diagenesis of middle Pennsylvanian (Desmoinesian) phylloid algal banks, Paradox Formation, Ismay zone, Ismay field and San Juan Canyon, Paradox Basin, Utah and Colorado: Colo. School of Mines M.S. Thesis, $315 \mathrm{p}$.

2. Brown, H.H., 1978, Marble Wash Field, in J.E. Fassett, ed., Oil and gas fields of the Four Corners area: Four Corners Geological Society, p. 143-145.

Buckner, D.H., and Groen, W., 1981, Squaw Canyon Field, San Juan County, Utah, in D.L. Wiegand, ed., Geology of the Paradox Basin: RMAG, p. 71-76.

Canfield, C.L., 1996, Doing business with the Ute Mountain Ute Tribe, in A.C. Huffman, W.R. Lund, and L.H. Godwin, eds., Geology and Resources of the Paradox Basin: Utah Geological Association and Four Corners Geological Society Guidebook 25, p. 9-12. 
Carlton, P.E., 1958, Geology and drilling history of the Big Flat, Cane Creek area, Grand County, Utah in A.F. Sanborn, ed., Guidebook to the geology of the Paradox Basin: Intermountain Association of Petroleum Geologists, p. 254-256.

Carr, W.E., and White, J.C., 1958, The Ismay Oil Field, in A.F. Sanborn, ed., Guidebook to the geology of the Paradox Basin: Intermountain Association of Petroleum Geologists, p. 278-279.

Cater, F.W., 1955, The salt anticlines of southwestern Colorado and southeastern Utah, in Cooper, J.C., ed., Geology of parts of Paradox, Black Mesa \& San Juan Basins: Four Corners Geological Society, p. 125-131.

Cater, F.W., 1970, Geology of the salt anticline region in southwestern Colorado: USGS Professional Paper 637, $80 \mathrm{p}$.

Cater, F.W., 1972, Salt anticlines within the Paradox Basin, in Geologic Atlas of the Rocky Mountain Region: RMAG, p. 137-138.

Cater. F.W., and Elston, D.P., 1963, Structural development of salt anticlines of Colorado and Utah: AAPG Memoir 2, Backbone of the Americas, p. 152-159.

Chidsey, T.C., Brinton, L., Eby, D.E., and Hartman, K., 1996, Carbonate-mound reservoirs in the Paradox Formation: an outcrop analogue along the San Juan River, southeastern Utah, in A.C. Huffman, W.R. Lund, and L.H. Godwin, eds., Geology and resources of the Paradox Basin: Utah Geological Association and Four Corners Geological Society Guidebook 25, p. 139-150.

Chidsey, T.C., Eby, D.E., and Lorenz, D.M., 1996, Geological and reservoir characterization of small shallow-shelf carbonate fields, southern Paradox Basin, Utah in A.C. Huffman, W.R. Lund, and L.H. Godwin, eds., Geology and resources of the Paradox Basin: Utah Geological Association and Four Corners Geological Society Guidebook 25, p. 39-56.

3. Choquette, P.W., 1983, Platy algal reef mounds, Paradox Basin, in P.A. Scholle, D.G. Bebout, and C.H. Moore, eds., Carbonate Depositional Environments, AAPG Memoir 33, p. 454-462.

Choquette, P.W., and Traut, J.D., 1963, Pennsylvanian carbonate reservoirs, Ismay Field, Utah and Colorado, in R.O. Bass, ed., A Symposium, Shelf carbonates of the Paradox Basin: Four Corners Geological Society, p. 157-184.

Clark, C.R., 1978, Lisbon field, in Fassett, J.E., ed., Oil and gas fields of the Four Corners area: Four Corners Geological Society, v. II, p. 662-665. 
Condon, S.M. 1987, Geologic framework of Precambrian to Jurassic rocks, Ute Mountain Ute Indian Reservation, Colorado and New Mexico: USGS Administrative Report 17-II-A.

Condon, S.M. 1995, Geology of pre-Pennsylvanian rocks in the Paradox Basin and adjacent areas, southeastern Utah and southwestern Colorado: USGS Bulletin 2000-G, 53 p.

Conner, D.C., and Wright, E.M., 1958, Bluff Field, in A.F. Sanborn, ed., Guidebook to the Geology of the Paradox Basin: Intermountain Association of Petroleum Geologists, p. 257-261.

4. Crawley-Stewart, C.L., 1995, 3D solution to a 2D pitfall: Seismic detection of carbonate buildups, Kiva Field, Paradox Basin, San Juan County, Utah, in R.R. Ray, ed., High-definition seismic: 2D, 2D swath and 3D case histories: RMAG, p. 177-183.

5. Dawson, W.C., 1988, Ismay reservoirs, Paradox Basin: diagenesis and porosity development, in S.M. Goolsby and M.W. Longman, eds., Occurrence and Petrophysical Properties of Carbonate Reservoirs in the Rocky Mountain Region: RMAG Symposium, p. 163-174.

Doelling, H.H. 1985, Geologic map of the Arches National Park and Vicinity, Grand County, Utah: Utah Geological and Mineral Survey Map 74, 15 p., 1 sheet.

Doelling, H.H., 1988, Geology of Salt Valley anticline and Arches National Park, Grand County, Utah: Utah Geological and Mineral Survey Bulletin 122, p. 1-58.

Dubiel, R.F., Huntoon, J.E., Condon, S.M., and Stanesco, J.D., 1996, Permian deposystems, paleogeography, and paleoclimate of the Paradox Basin and vicinity, in M.W. Longman and M.D. Sonnenfeld, eds., Paleozoic systems of the Rocky Mountain Region, RMAG \& SEPM, p. 427-444.

Elias, G.K., 1963, Habitat of Pennsylvanian algal bioherms, Four Corners area, in R.O. Bass, ed., A Symposium, Shelf Carbonates of the Paradox Basin: Four Corners Geological Society, p. 185-203.

Elston, D.P., and Shoemaker, E.M., 1961, Preliminary structure contour map on top of salt in the Paradox Member of the Hermosa Formation in the Salt Anticline region, Colorado and Utah: USGS Oil \& Gas Investigations Map OM-205.

Elston, D.P., and Shoemaker, E.M., 1963, Salt anticlines of the Paradox Basin, Colorado and Utah, in Symposium on Salt: Northern Ohio Geological Society, p. 131-146. 
Fenex, W.D., and Lee, C.V., 1958, White Mesa Field, in A.F. Sanborn, ed., Guidebook to the geology of the Paradox Basin: Intermountain Association of Petroleum Geologists,

p. 288-289.

Fetzner, R.W., 1960, Pennsylvanian paleotectonics of the Colorado Plateau: AAPG Bulletin, v. 44, no. 8, p. 1371-1413.

Fouret, K.L., 1982, Depositional and diagenetic environments of the Mississippian Leadville Formation at Lisbon Field, Utah: M.S. Thesis, Texas A\&M University, $120 \mathrm{p}$.

Fouret, K.L., 1996, Depositional and diagenetic environments of the Mississippian Leadville Limestone at Lisbon Field, Utah, in A.C. Huffman, W.R. Lund, and L.H. Godwin, eds., Geology and resources of the Paradox Basin: Utah Geological Association and Four Corners Geological Society Guidebook 25, p. 129-138.

$\mathrm{Ge}, \mathrm{H}$. 1996, Kinematics and dynamics of salt tectonics in the Paradox Basin, Utah and Colorado: field observations and scaled modeling: Ph.D. Dissertation, University of Texas, $317 \mathrm{p}$.

Ge, H., Jackson, M.P.A., and Vendeville, B.C., 1996, Extensional origin of breached Paradox diapirs, Utah and Colorado: field observations and scaled physical models, in A.C. Huffman, W.R. Lund, and L.H. Godwin, eds., Geology and resources of the Paradox Basin: Utah Geological Association and Four Corners Geological Society Guidebook 25, p. 285-293.

Gerling, C.R., 1983, McElmo Dome Leadville carbon dioxide field, Colorado, in J.E. Fassett, ed., Oil and gas fields of the Four Corners area: Four Corners Geological Society, vol III, p. 735-739.

6. Ghazal, R.L., 1978, Desert Canyon Field, in J.E. Fassett, ed., Oil and gas fields of the Four Corners area: Four Corners Geological Society, p. 116-117.

Gianniny, G.L., 1995, Facies and sequence stratigraphic evolution of the mixed carbonate-siliciclastic strata, lower Desmoinesian, southwest Paradox Basin: Ph.d. Thesis, University of Wisconsin-Madison.

Gianniny, G.L., and Simo, J.A.T., 1996, Implication of unfilled accommodation space for sequence stratigraphy on mixed carbonate-siliciclastic platforms - an example from the lower Desmoinesian (Middle Pennsylvanian), southwestern Paradox Basin, in Longman, M.W., and Sonnenfeld, M.D., eds., Paleozoic systems of the Rocky Mountain region: RMAG \& SEPM, p. 213-234. 
Gloyn, R.W., Morgan, C.D., Tabet, D.E., Blackett, R.E., Tripp, B.T., and Lowe, M., 1995, Mineral, energy and ground-water resources of San Juan County, Utah: Utah Geological Survey Special Study 86, 24 p., 15 plates.

Goldhammer, R.K, Oswald, E.J., and Dunn, P.A., 1991, Hierarchy of stratigraphic forcing - example from Middle Pennsylvanian shelf carbonates of the Paradox Basin, in Franseen, E.K., Watney, W.L., Kendall, C.G., and Ross, W., eds., Sedimentary modeling: Kansas Geological Survey Bulletin 233, p. 361-413.

Goldhammer, R.K., 1994, High frequency, glacio-eustatic cyclicity in Middle Pennsylvanian of the Paradox Basin - an evaluation of Milankovitch forcing, in deBoer, P.L., and Smith, D.G., eds., Orbital forcing and cyclical sequences: Special publication of the International Association of Sedimentologists 19, p. 243-283.

Grammer, G.M., Eberli, G.P., Van Buchem, F.S.P., Stevenson, G.M., and Homewood, P., 1996, Application of high-resolution sequence stratigraphy to evaluate lateral variability in outcrop and subsurface - Desert Creek and Ismay intervals, Paradox Basin, in Paleozoic Systems of the Rocky Mountain Region: Rocky Mountain Section SEPM, p. 235-266.

7. Gray, R.S., 1967, Cache field - a Pennsylvanian algal reservoir in southwestern Colorado: AAPG Bulletin, v. 51, no. 10, p. 1959-1978.

Grove, K.W., Bayne, R.M., and Horgan, C.C., 1993, The Cane Creek clastic interval of the Pennsylvanian Paradox -an exciting new horizontal target, part II: Horizontal drilling technology: A case study [abs]: AAPG Bulletin, v. 77, no. 8, p. 1449.

Grummon, M., 1993, Exploring the self-sourcing Cane Creek zone of the Paradox Formation with horizontal wells [abs]: AAPG Bulletin, v. 77, no. 8, p. 1450.

Gustafson, V.O., 1981, Petroleum geology of the Devonian and Mississippian rocks of the Four Corners region, in Wiegand, D.L., ed., Geology of the Paradox Basin, RMAG, p. 101-109.

Gwynn, J.W., 1995, Resistivities and chemical analysis of selected oil and gas field, water well, and spring water, Utah: Utah Geological Survey Circular 87, 142 p.

Gwynn, J.W., 1996, Character and distribution of subsurface water and brine of the Paradox Basin, southeastern Utah, in A.C. Huffman, W.R. Lund, and L.H. Godwin, eds., Geology and resources of the Paradox Basin: Utah Geological Association and Four Corners Geological Society Guidebook 25, p. 351-361. 
Hanshaw, B.B. and Hill, G.H, 1969, Geochemistry and hydrodynamics of the Paradox basin region, Utah, Colorado and New Mexico, in Angino, E.E. and Billings, G.K., eds., Special Issue, Geochemistry of Subsurface Brines: Chemical Geology, v. 4, no. 1-2, March 1969, Elsevier Publishing Company, p. 263-294.

Harr, C.L., 1995, Paradox oil and gas potential of the Ute Mountain Ute Reservation: Phase I Administrative Report on File with Tribe, Towaoc, Colo., 41 p.

Harr, C.L. 1996, Paradox oil and gas potential of the Ute Mountain Ute Reservation, Phase II Administrative Report on file with Ute Mountain Ute Tribe, Towaoc, Colo., $55 \mathrm{p}$.

8. Harr, C.L., 1996, Paradox oil and gas potential of the Ute Mountain Ute Indian Reservation, in A.C. Huffman, W.R. Lund, and L.H. Godwin, eds., Geology and Resources of the Paradox Basin: Utah Geological Association and Four Corners Geological Society Guidebook 25, p. 13-28.

Harrison, T.S., 1927, Colorado-Utah salt domes: AAPG Bulletin, v. 11, p.111133.

Hart, B.S., Ralser, S., Cooper, S.P., Herrin, M., Nikolaissen, K., and Balch, R.S., 2001, Ute Dome I: Multidisciplinary integration defines Dakota reservoir compartment, in Anderson, D.S., Robinson, J.W. Estes-Jackson, J.E. and Coalson, E.B., eds., Gas in the Rockies, RMAG, p. 309-322.

Hart, B.S., Ralser, S., Cooper, S.P., Herrin, M., Nikolaissen, K., and Balch, R.S., 2001, Ute Dome II: 3D seismic attribute-based detection of fractured-swarm sweet spots in Paradox (Pennsylvanian), in Anderson, D.S., Robinson, J.W. Estes-Jackson, J.E. and Coalson, E.B., eds., Gas in the Rockies, RMAG, p. 323335.

Hartman, L., 1996, The Ute Mountain Ute Tribe (Weeminuche Band of Ute Nation), in A.C. Huffman, W.R. Lund, and L.H. Godwin, eds., Geology and Resources of the Paradox Basin: Utah Geological Association and Four Corners Geological Society Guidebook 25, p. 1-7.

Haynes, D.D., Vogel, J.D., and Wyant, D.G., 1972, Geology, structure and uranium deposits of the Cortez quadrangle Colorado and Utah: USGS Map I629.

Herman, G., and Sharp, S.L., 1956, Pennsylvanian and Permian stratigraphy of the Paradox Salt Embayment, in Intermountain Association of Petroleum Geologists $7^{\text {th }}$ Field Conference, 1960, p. 86-89. 
Herman, G., and Barkell, C.A., 1957, Pennsylvanian stratigraphy and productive zones, Paradox Salt Basin: AAPG Bulletin, v. 41, no. 5, p. 861-881.

Herrod, W.H., Roylance, M.H., and Strathouse, E.C., 1985, Pennsylvanian phylloid-algal mound production at Tin Cup Mesa Field, Paradox Basin, Utah, in M.W. Longman, K.W. Shanley, R.F. Lindsay, and D.E. Eby, eds., Rocky Mountain Carbonate Reservoirs - A Core Workship: SEPM Core Workship \#7, p. 409-445.

9. Herrod, W. H., and Gardner, P.S., 1988, Upper Ismay reservoir at Tin Cup Mesa Field, in S.M. Goolsby and M.W. Longman, eds., Occurrence and petrophysical properties of carbonate reservoirs in the Rocky Mountain region: RMAG, p. 175192.

Hintze, L.F., 1993, Geologic history of Utah: BYU Special Publication 7, 202 p.

Hite, R.J., 1960, Stratigraphy of the saline facies of the Paradox Member of the Hermosa Formation of southeastern Utah and southwestern Colorado, in Guidebook on the geology of the Paradox basin fold and fault belt, Four Corners Geological Society $3^{\text {rd }}$ Field Conference, p. 86-89.

Hite, R.J., 1970, Shelf carbonate sedimentation controlled by salinity in the Paradox basin, southeast Utah, in Ran, J.L. and Dellwig, L.F., eds., Third Symposium on Salt: Northern Ohio Geological Society, v. 1, p. 48-66.

Hite, R.J., 1972 or 1973 ?, Shelf carbonate sedimentation controlled by salinity in the Paradox Basin, southeast Utah: The Mountain Geologist, v. 9, no. 2-3, p.329-344.

Hite, R.J., 1978, Geology of the Lisbon Valley potash deposits, San Juan County, Utah: USGS Open File Report 78-148, 21 p.

Hite, R.J., Cater, F.W., and Liming, L.A., 1972, Pennsylvanian rocks and salt anticlines, Paradox basin, Utah and Colorado, in Mallory, W.W., ed., Geological atlas of the Rocky Mountain region: RMAG, p. 133-138.

Hite, R.J., and Lohman, S.W., 1973, Geological appraisal of Paradox Basin salt deposits for waste emplacement: USGS Open File Report 73-114, 75 p.

Hite, R.J., and Buckner, D.H., 1981, Stratigraphic correlation, facies concepts and cyclicity in Pennsylvanian rocks of the Paradox basin, in Wiegand, D.L., ed., Geology of the Paradox Basin: RMAG 1981 Guidebook, p. 147-159.

Hite, R.J., Anders, D.E., and Ging, T.G., 1984, Organic-rich source rocks of Pennsylvanian age in the Paradox Basin of Utah and Colorado, in Woodward, J., 
Meissner, F.F., and Clayton, J.L., eds., Hydrocarbon source rocks of the greater Rocky Mountain region: RMAG Guidebook, p. 255-274.

Hudec, M.R., 1995, The Onion Creek salt diapir: as exposed diapir fall structure in the Paradox Basin, Utah, in Travis, C.J., Harrison, H., Hudec, M.R., Vendeville, B.C., Peel, F.J., and Perkins, B.F., eds., Salt, sediment and hydrocarbons: Gulf Coast Section of SEPM Sixteenth Annual Research Conference, p. 125-134.

Huntoon, P.W., and Richter, H.R., 1979, Breccia pipes in the vicinity of Lockhart Basin, Canyonlands area, Utah: Four Corners Geological Society Guidebook, $9^{\text {th }}$ Field Conference, p. 47-53.

Irwin, C.D., 1963, Producing carbonate reservoirs in the Four Corners area, in R.O. Bass, ed., Shelf carbonates of the Paradox Basin: Four Corners Geological Society $4^{\text {th }}$ Annual Field Conference, p. 144-148.

Irwin, C.D., 1983, Stratigraphy and oil and gas production of southwest Colorado, in Fassett, J.E., ed., Oil and gas fields of the Four Corners area: Four Corners Geological Society, V. 3, p. 844-845.

Irwin, D., 1977, Paleozoic subsurface correlation in the Paradox Basin, Colo., N.M., and Utah, in RMAG Special Publication No. 2, Subsurface cross sections of Colorado.

Jackson, G.M., 1984, Seismic-stratigraphic study and analysis of a test line, Patterson field area, San Juan County, Paradox Basin, Utah: M.S. Thesis, Colorado School of Mines, $82 \mathrm{p}$.

Johnson J.F., and Groen, W., 1995, Seismic structure and seismic stratigraphy of the giant Aneth Field area of southeastern Utah, in R.R. Ray and B. Pearson, compilers, First RMAG \& DGS 3-D Seismic Symposium, 6 p.

Keighin, C.W., 1996, Petroleum geology and hydrocarbon potential of pre-Dakota strata, western portion of the Southern Ute Indian Reservation, Colorado, in A.C. Huffman, W.R. Lund, and L.H. Godwin, eds., Geology and Resources of the Paradox Basin: Utah Geological Association and Four Corners Geological Society Guidebook 25, p. 29-37.

Kelley, V.C., 1958, Tectonics of the region of the Paradox Basin, in Sanborn, A.F., ed., Guidebook to the geology of the Paradox Basin: Intermountain Association of Petroleum Geologists, p. 31-38.

Kelly, M.A., 1994, Carbonate buildups of the lower Desmoinesian Barker Creek interval, SE Utah: M.S. Thesis, University of Wisconsin-Madison. 
Kitcho, C.A. 1981, Characteristics of surface faults in the Paradox Basin, in Wiegand, D.L., ed., Geology of the Paradox Basin: RMAG, p. 1-21.

Krivanek, C.M., 1978, McElmo Field, Oil and gas fields of the Four Corners area: Four Corners Geological Society, p. 148-151.

Krivanek, C.M., 1978, Patterson Field, Oil and gas fields of the Four Corners area: Four Corners Geological Society, v. II, p. 688-690.

Krivanek, C.M., 1981, Bug Field, T36S, R25 and 26E, San Juan County, Utah, in D.L. Wiegand, ed., Geology of the Paradox Basin: RMAG Symposium, p. 47-54.

Krivanek, C.M., 1981, New fields and exploration drilling, Paradox Basin, Utah and Colorado, in D.L. Wiegand, ed., Geology of the Paradox Basin: RMAG Symposium, p. 77-81.

Latch, B.F., 1978, Little Valley Field, in Fassett, J.E., ed., Oil and gas fields of the Four Corners Area: Four Corners Geological Society, p. 670-672.

Lauth, R.E., 1958, Desert Creek Field, San Juan County, Utah, in A.F. Sanborn, ed., Guidebook to the Geology of the Paradox Basin: Intermountain Association of Petroleum Geologists, . 275-277.

Lauth, R.E., 1978, Mexican Hat, in Fassett, J.E., ed., Oil and gas fields of the Four Corners area: Four Corners Geological Society, p. 682-687.

Lehman, D.D., 1981, Productive Pennsylvanian carbonate mounds southwest of the Aneth area, Utah, in D.L. Wiegand, ed., Geology of the Paradox Basin: RMAG Symposium, p. 83-87.

Lehman, D., 1983, Papoose Canyon North Field, in J.E. Fassett, ed., Oil and gas fields of the Four Corners area: Four Corners Geological Society, vol. III, p. 892-894.

Likarish, D.M., Johnson J.F., and Groen, W. F., 1995, 2 1/2 D seismic exploration in the Greater Aneth Area of southeast Utah, in R.R. Ray and B. Pearson, compilers, First RMAG \& DGS 3-D Seismic Symposium, 5 p.

Louden, R.O., Lehman, D.D., Johnson, W.E., and Edwards, D.L., 1999, Horse Canyon Field - 3D seismic success and Ismay algal mound discovery, southern Paradox Basin, in R.R. Ray and B. Pearson, compilers, $5^{\text {th }}$ Annual 3D Seismic Symposium: RMAG \& DGS, 5 p.

10. Louden, R.O., Lehman, D.D., Johnson, W.E., and Edwards, D.L., 1999, Ismay algal mound discovery on 3D data brings new interest to the southern Paradox Basin, Utah: RMAG Website. 
Lowe, M., 1996, Ground-water resources of San Juan County, in A.C. Huffman, W.R. Lund, and L.H. Godwin, eds., Geology and resources of the Paradox Basin: Utah Geological Association and Four Corners Geological Society Guidebook 25, p. 389-394.

Lyons, T.R., 1958, Pennsylvanian oil and gas fields of the Paradox Basin: Symposium on Pennsylvanian Rocks of Colorado and Adjacent Areas: RMAG Symposium, p. 117-121.

Mack, G.H., and Miller, M.L., 1980, Pennsylvanian mud mound, Hermosa Group, southwestern Colorado: The Mountain Geologist, v. 17, no. 2, p.37-43.

Martin, G.W., 1981, Patterson Field, San Juan County, Utah, in D.L. Wiegand, ed., Geology of the Paradox Basin: RMAG, p. 61-69.

Martin, G.W. 1983, Bug field, in J.E. Fassett, ed., Oil and gas fields of the Four Corners area: Four Corners Geological Society, v. III, p. 1073-1077.

Matheny, J.P. and G.W. Martin, 1987, McClean Field, T37N, R19W, Montezuma County, Colorado in J.A. Campbell, ed., Geology of Cataract Canyon and Vicinity, $10^{\text {th }}$ Field Conference: Four Corners Geological Society Guidebook, p. 145-150.

Matheny, J.P. and G.W. Martin, 1987, Spargo Field, T38 \& 39N, R20W, Dolores County, Colorado in J.A. Campbell, ed., Geology of Cataract Canyon and Vicinity, $10^{\text {th }}$ Field Conference: Four Corners Geological Society Guidebook, p. 137-143.

Matheny, J.P., and M.W. Longman, 1996, Lower Desert Creek reservoirs in the Paradox Basin: Examples of phylloid algae filling depositional lows related to salt solution, in M.W. Longman and M.D. Sonnenfeld, eds., Paleozoic Systems of the Rocky Mountain Region: Rocky Mountain Section, SEPM, p. 267-282.

Matheny, M.L., 1978, Barker Creek Paradox, in Fassett, J.E., ed., Oil and gas fields of the Four Corners area: Four Corners Geological Society, v. 1, p. 201203.

11. McBride, B., and Rebne, C.A., 1997, Use of 2D and 3D seismic data to reduce drilling risk, Ismay algal-mound play, southern Paradox Basin, in E.B. Coalson, J.C. Osmond, and E.T. Williams, eds., Innovative Applications of Petroleum Technology in the Rocky Mountain Area: RMAG Symposium, p. 93-100.

McComas, M.R., 1963, Productive core analysis characteristics of carbonate rocks in the Four Corners area, in R.O. Bass, ed., Shelf carbonates of the 
Paradox Basin: Four Corners Geological Society $4^{\text {th }}$ Annual Conference, p. 149156.

McEachin, W.D., and Royce, R.M, 1978, Boundary Butte, in Fassett, J.E. ed., Oil and gas fields of the Four Corners area: Four Corners Geological Society, p. 615-620.

12. Mecham, D.F., 1978, Ismay Field, in J.E. Fassett, ed., Oil and gas fields of the Four Corners area: Four Corners Geological Society, p. 654-657.

13. Mecham, D.F., 1978, Ismay South Field, in J.E. Fassett, ed., Oil and gas fields of the Four Corners area: Four Corners Geological Society, p. 658-659.

Meisner, J.F., 1978, Papoose Canyon field, in J.E. Fassett, ed., Oil and gas fields of the Four Corners area: Four Corners Geological Society, vol. I, p. 154-156.

Mickel, E.G., 1978, McClean field, in J.E. Fassett, ed., Oil and gas fields of the Four Corners area: Four Corners Geological Society, vol. I, p. 146-148.

Mickel, E.G., 1978, Wilson Canyon, in J.E. Fassett, ed., Oil and gas fields of the Four Corners area: Four Corners Geological Society, p. 719-721.

Miller, J.A., 1985, Depositional and reservoir facies of the Mississippian Leadville Formation, Northwest Lisbon Field, Utah, in P.O. Roehl and P.W. Choquette, eds., Carbonate Petroleum Reservoirs, Springer-Verlag, New York, p. 161-173.

Miser, H.D., 1924, Geologic structure of the San Juan Canyon and adjacent country, Utah: USGS Bulletin 751-D, p. 115-155.

Molenaar, C.M., 1981, Mesozoic stratigraphy of the Paradox Basin - an overview, in Wiegand, D.L., ed., Geology of the Paradox Basin: RMAG Guidebook, p. 119-127.

Molenaar, C.M., 1987, Correlation chart - Paradox Basin and vicinity, in Campbell, J.A., ed., Geology of Cataract Canyon and vicinity: Four Corners Geological Society 10th Field Conference, p. 17.

Montgomery, S.L., 1992, Paradox Basin - Cane Creek play, in Cheney, T. and Cain, D., eds., Petroleum Frontiers: Petroleum Information Corporation, v. 9, no. $1,66 \mathrm{p}$.

14. Montgomery, S.L., Chidsey, T.C., Eby, D.E., Lorenz, D.M., and Culham, W.E., 1999, Pennsylvanian carbonate buildups, Paradox Basin: Increasing reserves in heterogeneous, shallow-shelf reservoirs: AAPG Bulletin, v. 83, no. 2, p. 193-210. 
Morgan, C.D., 1992, "Cane Creek" exploration play area, Emery, Grand and San Juan counties, Utah: Utah Geological Survey-Open File Report 232, 15 p., 10 plates.

Morgan, C.D., 1992, Horizontal drilling potential of the Cane Creek Shale, Paradox Basin, Utah in J.W. Schmoker, E.B. Coalson, and C.A. Brown, eds., Geological Studies Relevant to Horizontal Drilling: Examples from Western North America: RMAG Symposium, p. 257-265.

Morgan, C.D., 1993, Horizontal-drilling technology re-opens old play: Utah Geological Survey, Survey Notes, v. 25, no. 3-4, p. 1-7.

Morgan, C.D., 1993, Paradox basin plays-overview, in Robertson, J.M., and Broadhead, R.F., project directors, Atlas of major Rocky Mountain gas reservoirs: New Mexico Bureau of Mines and Mineral Resources, p. 90.

Morgan, C.D., 1993, Paradox Formation, in Robertson, J.M., and Broadhead, R.F., project directors, Atlas of major Rocky Mountain gas reservoirs: New Mexico Bureau of Mines and Mineral Resources, p. 92-93.

Morgan, C.D., 1993, Leadville Limestone, in Robertson, J.M., and Broadhead, R.F., project directors, Atlas of major Rocky Mountain gas reservoirs: New Mexico Bureau of Mines and Mineral Resources, p. 94.

Morgan, C.D. 1994, Exploring for new oil in old fields, Salt Wash field, a case study: Utah Geological Survey Open File Report 307, 41 p., 2 plates, 3 diskettes.

Morgan, C.D., Yonkee, W.A., and Tripp, B.T., 1991, Geological considerations for oil and gas drilling on state potash leases at Cane Creek anticline, Grand and San Juan Counties, Utah: Utah Geological Survey Circular 84, 24 p.

Moriarty, B.J., and Grundy, R.J., 1985, Seismic exploration for Pennsylvanian algal mounds of the Paradox Basin, in R.R. Gries and R.C. Dyer, eds., Seismic Exploration of the Rocky Mountain Region, RMAG \& DGS Symposium, p. 143150.

Nuccio, V.F., and Condon, S.M., 1996, Burial and thermal history of the Paradox Basin, Utah and Colorado, and petroleum potential of the middle Pennsylvanian Paradox Formation, in A.C. Huffman, W.R. Lund, and L.H. Godwin, eds., Geology and Resources of the Paradox Basin: Utah Geological Association and Four Corners Geological Society Guidebook 25, p. 57-76.

Nuccio, V.F., and Condon, S.M, 1996, Burial and thermal history of the Paradox Basin, Utah and Colorado and petroleum potential of the Middle Pennsylvanian Paradox Formation: USGS Bulletin 2000-O, 41 p. 
Ohlen, H.R. and Mclntyre, L.B., 1965, Stratigraphy and tectonic features of Paradox Basin, Four Corners area: AAPG Bulletin, v. 49, no. 11, p. 2020-2040.

Oltmans, J.R., 1995, Prospect definition using cost-effective 2D swath in Rocky Mountain stratigraphic traps, in R.R. Ray, ed., High-Definition Seismic: 2D, 2D Swath and 3D Case Histories: RMAG Symposium, p. 87-100.

Parker, J.W., 1960, Big Flat Field, in K.E. Smith, ed., Geology of the Paradox Basin fold and fault belt: Four Corners Geological Society $3^{\text {rd }}$ Field Conference, p. 127-132.

Parker, J.M., 1961, The Cambrian, Devonian and Mississippian rocks and prePennsylvanian structure of southwest Colorado, and adjoining portions of Utah, Arizona and New Mexico, in Symposium on lower and middle Paleozoic rocks of Colorado: RMAG $12^{\text {th }}$ Annual Field Conference, p. 59-70.

Parker, J.M., 1961, The McIntyre Canyon and Lisbon oil and gas fields, San Miguel County, Colorado and San Juan County, Utah, in Symposium on lower and middle Paleozoic rocks of Colorado: RMAG $12^{\text {th }}$ Annual Field Conference, p. 163-173.

Parker, J.M., 1968, Lisbon Field area, San Juan County, Utah, in Beebe, W.B., and Curtis, B.F., eds., Natural Gases: AAPG Memoir 9, p. 1371-1388.

Parker, J.M., 1981, Lisbon Field area, San Juan County, Utah, in D.L. Wiegand, ed., Geology of the Paradox Basin: RMAG, p. 89-100.

Peterson, J.A., 1966, Genesis and diagenesis of Paradox Basin carbonate mound reservoirs: Wyoming Geological Association $20^{\text {th }}$ Annual Conference Guidebook, p. 67-86.

Peterson, J.A., 1966, Stratigraphic vs. structural controls on carbonate-mound hydrocarbon accumulation, Aneth area, Paradox Basin: AAPG Bulletin, v. 50, no. 10 , p. $2068-2081$.

Peterson, J.A., 1989, Geology and petroleum resources, Paradox basin province: USGS Open File Report 88-450, 69 p.

Peterson, J.A., 1992, Aneth Field - U.S.A., Paradox Basin, Utah, in AAPG Treatise of Petroleum Geology, Atlas of Oil and Gas Fields, Stratrigraphic Traps III, p. 41-82.

15. Peterson, J.A., and Hite, R.J., 1969, Pennsylvanian evaporite-carbonate cycles and their relation to petroleum occurrence, southern Rocky Mountains: AAPG Bulletin, v. 53, no. 4, p. 884-908. 
Peterson, J.A., and Ohlen, H.R., 1963, Pennsylvanian shelf carbonates, Paradox basin, in Bass, R.O., ed., Shelf carbonates of the Paradox Basin: Four Corners Geological Society Symposium, $4^{\text {th }}$ Field Conference, p. 65-79.

Peterson, P.R., 1972, Salt Wash Field, Grand County, Utah: Utah Geological and Mineralogical Survey Oil and Gas Field Studies, No. 4.

16. Petroleum Frontiers, 1984, Paradox Basin: Unraveling the mystery: Petroleum Information Incorporated, $54 \mathrm{p}$.

Phillip, M., 1975, Cane Creek mine solution mining project Moab potash operations, Texasgulf Inc., in Fassett, J.E., ed., Oil and gas fields of the Four Corners area: Four Corners Geological Society, p. 1089-1091.

Picard, M.D., 1958, Subsurface structure, Aneth and adjacent area, San Juan County, Utah, in A.F. Sanborn, ed., Guidebook to the Geology of the Paradox Basin: Intermountain Association of Petroleum Geologists, p. 226-230.

Picard, M.D., 1959, White Mesa Field, environmental trap, San Juan County, Utah: AAPG Bulletin, v. 43, no. 10, p. 2456-2469.

Picard, M.D., 1960, Geology of Pennsylvanian gas in the Four Corners region: AAPG Bulletin, v. 44, no. 9, p. 1541-1569.

Picard, M.D., 1960, Carbon dioxide, nitrogen and helium in the Mississippian of the Four Corners region, Preliminary Statement: Four Corners Geological Society $3^{\text {rd }}$ Field Conference Guidebook, p. 138-140.

Picard, M.D., 1962, Occurrence and origin of Mississippian gas in Four Corners region: AAPG Bulletin, v. 46, no. 9, p. 1681-1700.

Picard, M.D., Brown, B.R., Loleit, A.J., and Parker, J.W., 1968, Outline of occurrence of Pennsylvanian gas in Four Corners region, in B.W. Beebe, ed., Natural gases of North America: AAPG Memoir 9, p. 1327-1356.

Pray, L.C., and Wray, J.L., 1963, Porous algal facies (Pennsylvanian) Honaker Trail, San Juan County, Utah, in Bass, R.O., ed., Shelf carbonates of the Paradox Basin: Four Corners Geological Society Symposium, p. 204-234.

Quigley, W.D., 1958, Aneth field and surrounding areas, in A.F. Sanborn, ed., Guidebook to the Geology of the Paradox Basin: Intermountain Association of Petroleum Geologists, p. 247-253.

Raup, O.B., and Hite, R.J., 1992, Lithology of evaporite cycles and boundaries in the upper part of the Paradox Formation of the Hermosa group of Pennsylvanian age in the Paradox Basin, Utah and Colorado: USGS Bulletin 2000-B, 37 p. 
Reid. F.S., and Stevenson, G., 1978, Gothic Mesa Field, San Juan County, Utah: in J.E. Fassett, ed., Oil and gas fields of the Four Corners area: Four Corners Geological Society, p. 642-645.

17. Reid, F.S. and Berghorn, C.E., 1981, Facies recognition and hydrocarbon potential of the Pennsylvanian Paradox Formation in D.L. Wiegand, ed., Geology of the Paradox Basin: RMAG Symposium, p. 111-117.

Robinson, B.B., 1958, Ratherford Field, San Juan County, Utah, in A.F. Sanborn, ed., Guidebook to the Geology of the Paradox Basin: Intermountain Association of Petroleum Geologists, p. 282-285.

Roth, G., 1983, Alkali Gulch-West, in Fassett, J.E., ed., Oil and gas fields of the Four Corners area: Four Corners Geological Society, v. 3, p. 867-868.

Roylance, M.H., 1990, Depositional and diagenetic history of a Pennsylvanian algal-mound complex: Bug and Papoose Canyon fields, Paradox Basin, Utah and Colorado: AAPG Bulletin, v. 74, no. 7, p. 1087-1099.

Sass, J.H., Lachenbruch, A.H., and Smith, E.P., 1983, Thermal data from well GD-1, Gibson Dome, Paradox Valley, Utah: USGS OFR 83-476, 15 p.

Scott, G.L., and Klipping, S., 1981, Seismic surveying, salt anticline region, Paradox Basin, in Wiegand, D.L., ed., Geology of the Paradox Basin, RMAG, p. 161-168.

Sheffer. B.D., Boundary Butte area, San Juan and Apache counties, Utah and Arizona, in A.F.Sanborn, ed., Guidebook to the Geology of the Paradox Basin: Intermountain Association of Petroleum Geologists, p. 262-267.

Sherrill, F.G., 1979, Seismic modeling of Pennsylvanian carbonate mounds in the Paradox Basin: M.S. Thesis, Colorado School of Mines, $182 \mathrm{p}$.

Shoemaker, E.M., Case, J.E. and Elston, D.P., 1958, Salt anticlines of the Paradox Basin (Colorado-Utah), in Guidebook to the geology of the Paradox Basin: Intermountain Association of Petroleum Geologists Guidebook, $9^{\text {th }}$ Field Conference, p. 39-59.

Smith, K.T., and Prather, O.E., 1981, Lisbon Field - Lessons in exploration, in Wiegand, D.L., ed., Geology of the Paradox Basin, RMAG Guidebook, p. 55-59.

Smouse, DeForrest, 1993, Boundary Butte, in Hill, B.G., and Bereskin, R.S., eds., Oil and gas fields of Utah: Utah Geological Association Publication 22. 
Spalding, R.W., 1955, Desert Creek Field, San Juan County, Utah, in J.C. Cooper, ed., Geology of parts of Paradox, Black Mesa and San Juan Basins: Four Corners Geological Society, p. 166-167.

18. Spencer, C.W., 1978, Towaoc, in J.E. Fassett, ed., Oil and gas fields of the Four Corners Area: Four Corners Geological Society, p. 164-167,

Spragg, J., 1952, Boundary Butte Anticline, in S.A. Wengard, ed., Geological Symposium of the Four Corners Region: Four Corners Geological Society, p. 104-106.

Squires, B.W., 1978, Alkali Gulch, in Fasset, J.E., ed., Oil and gas fields of the Four Corners area: Four Corners Geological Society, v. 1, p. 103-104.

Stevenson, G.M. and Baars, D.L., 1977, Pre-Carboniferous paleotectonics of the San Juan Basin, in J.E., Fassett, ed., New Mexico Geological Society Guidebook, $28^{\text {th }}$ Field conference, San Juan Basin III, p. 99-110.

Stevenson, G.M., and Baars, D.L. 1986, The Paradox - a pull-apart basin of Pennsylvanian age, in Peterson, J.A., ed., Paleotectonics and sedimentation: AAPG Memoir 41, p. 513-539.

Stevenson, G.M., and Baars, D.L., 1988, Overview: Carbonate reservoirs of the Paradox Basin, in S.M. Goolsby and M.W. Longman, eds., Occurrence and petrophysical properties of carbonate reservoirs in the Rocky Mountain region, RMAG 1988 Symposium, p. 148-162.

Stewart, C.L.C., 1995, 3D solution to a 2D pitfall: Seismic detection of carbonate buildups, Kiva field, Paradox Basin, San Juan County, Utah, in R.R. Ray, ed., High-Definition Seismic: 2D, 2D swath and 3D Case Histories: RMAG Symposium, p. 177-183.

Stokes, W.L., 1948, Geology of the Utah-Colorado salt dome region with emphasis on Gypsum Valley, Colorado: Guidebook to the geology of Utah No. 3, Salt Lake City, Utah, $50 \mathrm{p}$.

Sugiura, R., and Kitcho, C.A., 1981, Collapse structures in the Paradox Basin, in Wiegand, D.L., ed., Geology of the Paradox Basin, RMAG Guidebook, p. 33-45.

Szabo, E., and Wengard, S.A., 1975, Stratigraphy and tectnogenesis of the Paradox basin, in Fassett, J.E., ed., Canyonlands Country: Four Corners Geological Society Guidebook， $8^{\text {th }}$ Field Conference, p. 193-210.

Tezak, M.A., 1978, Ute Dome Paradox, in Fassett, J.E., ed., Oil and gas fields of the Four Corners area: Four Corners Geological Society, v. 2, p. 546-547. 
Thackston, J.W., McCulley, B.L., and Preslo, L.M., 1981, Ground-water circulation in the western Paradox Basin, Utah, in Wiegand, D.L., ed., Geology of the Paradox Basin: RMAG Guidebook, p. 201-225.

Thomaidis, N., 1978, Stratigraphy and oil and gas production of southwest Colorado, in Fassett J.E., ed., Oil and gas fields of the Four Corners area: Four Corners Geological Society, v. 1, p 43-44.

Weber, L.J., Huffman, A.C., Sarg. J.F., and Wright, F.M., 1994, High-resolution sequence stratigraphy: reservoir description and geologic setting of the giant Aneth oil field, SE Utah - a field guide to exposures along the San Juan River Canyon: Field Trip Guidebook AAPG/RMAG Field Trip \#2, 69 p.

Weber, L.J., Sarg, J.F., and Wright, F.M., 1995, Sequence stratigraphy and reservoir delineation of the Middle Pennsylvanian (Desmoinesian), Paradox basin and Aneth field, Milankovitch sea-level changes, cycles, and reservoirs on carbonate platforms in greenhouse and ice-house worlds: SEPM Short Course No. 35 , p. 1-81.

Weber. L.J., Wright, F.M., Sarg, J.F., Shaw, E., Harman, L.P., Vanderhill, J.B., and Best, D.A.,1995, Reservoir delineation and performance: Applications of sequence stratigraphy and integration of petrophysics and engineering data, Aneth field, southeast Utah, U.S.A., in E.L. Stoudt and P.M. Harris, eds., Hydrocarbon reservoir characterization: Geologic framework and flow unit modeling: SEPM Short Course 34, p. 1-30.

Webring, M.W., and Gerda, A.A., 1996, A gravity and magnetic survey of the Ute Mountain Ute Indian Reservation, Colorado and New Mexico, in A.C. Huffman, W.R. Lund, and L.H. Godwin, eds., Geology and resources of the Paradox Basin: Utah Geological Association and Four Corners Geological Society Guidebook 25, p. 221-228.

Wengard, S.A., 1951, Reef limestones of Hermosa Formation, San Juan County, Utah: AAPG Bulletin, v.35, p. 1038-1051.

Wengard, S.A., 1955, Biohermal trends in Pennsylvanian strata of San Juan Canyon, San Juan County, Utah, in J.C. Cooper, ed., Geology of parts of Paradox, Black Mesa and San Juan basins: Four Corners Geological Society, p. 70-77.

Wengard, S.A., 1955, Mexican Hat Oil Field, San Juan County, Utah, in J.C. Cooper, ed., Geology of parts of Paradox, Black Mesa and San Juan basins: Four Corners Geological Society, p. 150-163. 
Wengard, S.A., 1962, Pennsylvanian sedimentation in Paradox Basin, Four Corners region, in Pennsylvanian System in the United States: AAPG Special Volume, p. 264-330.

Wengard, S.A., 1973, Regional stratigraphic control of the search for Pennsylvanian petroleum, southern Monument Upwarp, southeastern Utah, in New Mexico Geological Society $24^{\text {th }}$ Field Conference Guidebook of Monument Valley and vicinity, Arizona and Utah, p. 122-138.

Wengard, S.A., and Strickland, J.W., 1954, Pennsylvanian stratigraphy of Paradox Salt Basin, Four Corners region, Colorado and Utah: AAPG Bulletin, v. 38 , no. 10, p. 2157-2199.

Wengard, S.A., and Matheny, M.L., 1958, Pennsylvanian system of Four Corners region: AAPG Bulletin, v. 42, p. 2048-2106.

White, J.V., 1995, Diagenesis and porosity distribution of Pennsylvanian Paradox Formation carbonates (Upper Ismay), southeast Utah: M.S. Thesis, University of Texas, $100 \mathrm{p}$.

White, J.V., and Kirkland, B.L., 1996, Diagenesis and porosity distribution of Pennsylvanian Paradox Formation carbonates (Upper Ismay), southeastern Utah, in A.C. Huffman, W.R. Lund, and L.H. Godwin, eds., Geology and resources of the Paradox Basin: Utah Geological Association and Four Corners Geological Society Guidebook 25, p. 151-160.

Williams, M.R., 1996, Stratigraphy of Upper Pennsylvanian cyclical carbonate and siliciclastic rocks, western Paradox Basin, Utah, in M.W. Longman and M.D. Sonnenfeld, eds., Paleozoic systems of the Rocky Mountain Region, RMAG \& SEPM, p. 283-304.

Williams, P.L., 1964, Geology, structure and uranium deposits of the Moab quadrangle, Colorado and Utah: USGS Map I-360.

Williams-Stroud, S., 1994, The evolution of an inland sea of marine origin to a non-marine saline lake: the Pennsylvanian Paradox salt, in R.W. Renaut and W.R. Lase, eds., Sedimentology and geochemistry of modern and ancient saline lakes: SEPM Special Publication 50, p. 293-306.

Witkind, I.J., 1964, Geology of the Abajo Mountain area, San Juan County, Utah: USGS Professional Paper 453, $110 \mathrm{p}$.

Witkind, I.J., 1975, The Abajo Mountains: an example of the laccolithic groups on the Colorado Plateau: Four Corners Geological Society Guidebook, $8^{\text {th }}$ Field Conference, Canyonlands Country, p. 245-252. 
19. Wold, J.T., 1978, Cache Field, in J.E. Fassett, ed., Oil and gas fields of the Four Corners area: Four Corners Geological Society, p. 108-110.

Woodard-Clyde Consultants 1982, Geologic characterization report for the Paradox Basin study region, Utah study areas, regional overview: ONWI-290, v. 1.

Woodard-Clyde Consultants 1982, Geologic characterization report for the Paradox Basin study region, Utah study areas, Lisbon Valley: ONWI-290, v. 4.

Woodward-Clyde Consultants, 1982, Geologic characterization report for the Paradox basin study region, Utah study areas-volume V: Office of Nuclear Waste Isolation, ONWI-290, p. A1-A24.

Woodward-Clyde Consultants, 1983, Overview of the regional geology of the Paradox basin study region - technical report, US Dept of Energy, Office of Nuclear Waste Isolation, ONWI-92, 433 p.

\subsection{Field summaries in Clem \& Brown, 1984:}

$\begin{array}{ll}20 . & \text { Ismay } \\ 21 . & \text { Ismay South } \\ 22 . & \text { McElmo Mesa } \\ 23 . & \text { Rockwell Flat }\end{array}$

Fields summaries in Hill \& Bereskin, 1993:

Alkali Canyon - Upper Ismay

Bartlett Flat/Big Flat - Cane Creek, Leadville

Bluff - Lower Ismay, Desert Creek

Boundary Butte - De Chelly, Lower Ismay (low BTU)

Cave Canyon - Upper Ismay

Cherokee - Upper Ismay

Deadman - Upper Ismay

Greater Aneth - Desert Creek

Hatch - Desert Creek

Kachina - Upper Ismay

Kiva - Upper Ismay

Lightning Draw - Lower Ismay

Lisbon - Leadville

Little Nancy - Upper Ismay

McCracken Spring - Upper Ismay

Mexican Hat - Pennsylvanian

Salt Wash - Leadville

Tin Cup Mesa - Upper Ismay 


\section{LIST OF ACRONYMS AND ABBREVIATIONS}

3D3C - three dimensional, three component

3D9C - three dimensional, nine component

AVO - amplitude variation with offset

RMS - Root Mean Square

RW - Red Willow Production

SU - Southern Ute Tribe

UM - Ute Mountain Ute Tribe 